Review

\title{
Bioenergy technologies adoption in Africa: A review of past and current status
}

\author{
Samuel Olatunde Dahunsi ${ }^{\mathrm{a},{ }^{*}}$, Omololu Oluwatobi Fagbiele ${ }^{\mathrm{b}}$, Esther Ojima Yusuf ${ }^{\mathrm{b}}$ \\ a Sustainable Management of Natural Resources and Environment Research Group, Environment and Labour Safety, Ton Duc Thang University, Ho Chi Minh \\ City, Viet Nam \\ ${ }^{\mathrm{b}}$ Department of Chemical Engineering, Covenant University, Ota, Ogun State, Nigeria
}

\section{A R T I C L E I N F O}

\section{Article history:}

Received 6 January 2020

Received in revised form 28 March 2020

Accepted 11 April 2020

Available online 17 April 2020

Handling editor is Prof. Jiri Jaromir Klemeš

\section{Keywords:}

Africa

Bioenergy

Biomass

Development

Energy

Environment

\begin{abstract}
A B S T R A C T
One of the major indicators of social and economic development of a nation is energy. The global development in energy production has so grown that there are currently less than a billion people without access to electricity. However, Africa has again been left out of this mundane progress while Asia with about the same energy dilemma was able to provide electric energy to 375 million of its citizenry between 2011 and 2017. Meanwhile, India, Bangladesh, and Indonesia were all able to provide over 80\% electrification rates to their teeming population. Though some levels of improvement have been witnessed in Africa's electrification projects up to about 43\%, the slow pace of development in comparison with other parts of the globe is very worrisome especially due to the ever-increasing human population being witnessed across the African continent. This explains why yet over 600 million African are still living without access to electricity. Therefore, this paper examines the past and current status of bioenergy development across Africa while advocating for the inclusion of bioenergy in the African future energy projection due to their immense potentials to transform the continent. Africa stands a chance of becoming a major player in the global energy market.
\end{abstract}

() 2020 Elsevier Ltd. All rights reserved.

\section{Contents}

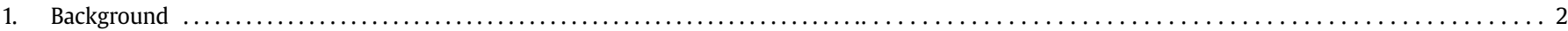

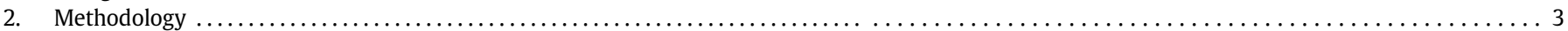

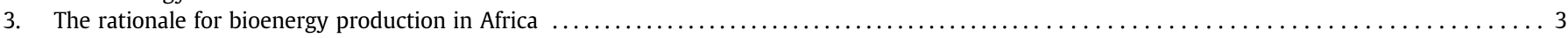

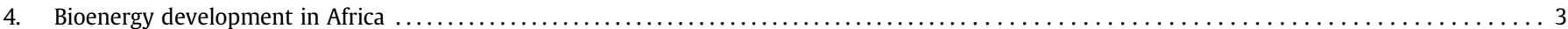

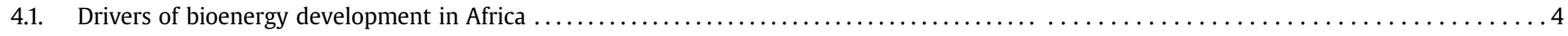

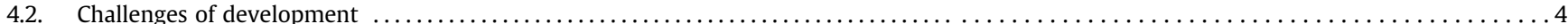

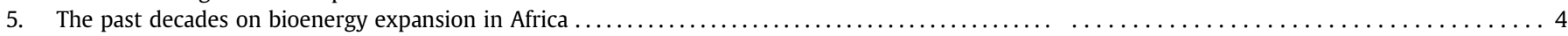

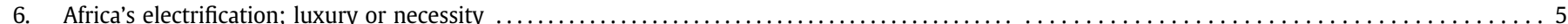

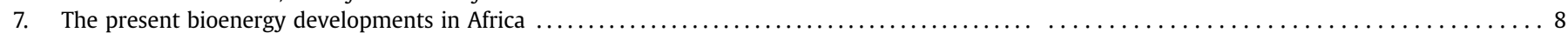

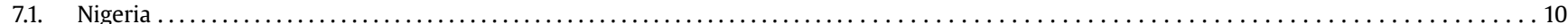

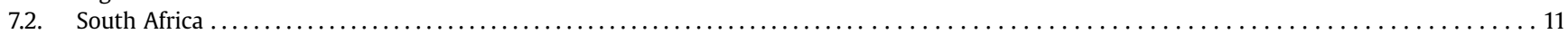

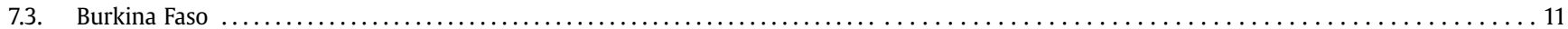

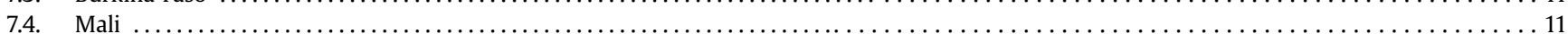

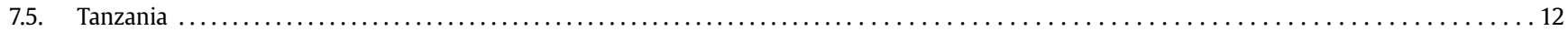

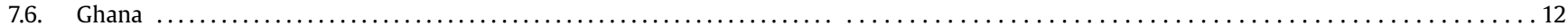

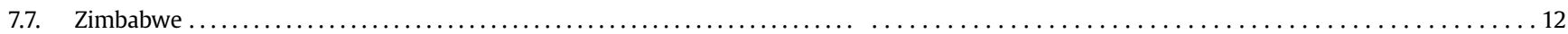

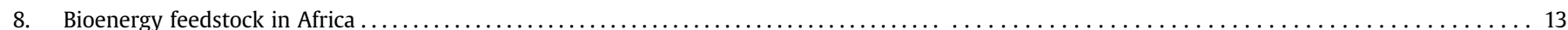

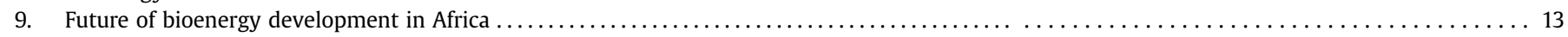

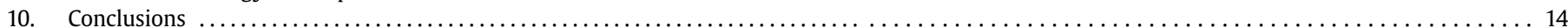

\footnotetext{
* Corresponding author.

E-mail address: dahunsi.olatunde.samuel@tdtu.edu.vn (S.O. Dahunsi).
} 


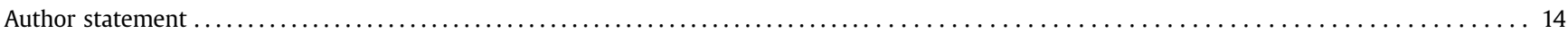

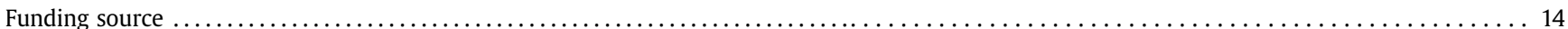

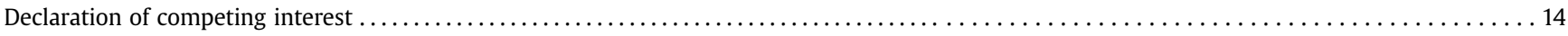

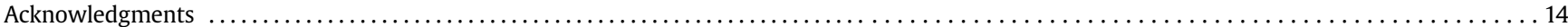

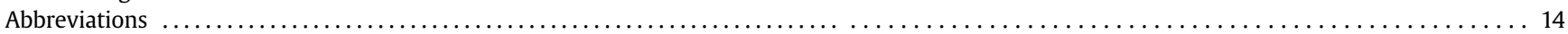

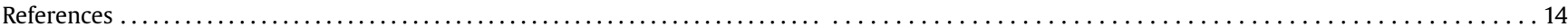

\section{Background}

Energy availability is a major factor in national development especially in terms of production and adequate distribution of affordable, renewable and sustainable environment-friendly energies (Jain and Jain, 2017; Shane et al., 2017; Ye et al., 2016). This critical factor stands as one of the major challenges faced in most developing countries of Africa where a high percentage of the populace relies perpetually on hazardous practices such as direct burning of biomass and animal dungs in order to obtain energy for cooking and heating (Chirambo, 2016; Kamp and Bermúdez Forn, 2016; Mengistu et al., 2016). The resultant effects of this are much and chief among them is the low per capita energy consumption of 681 kgoe across most Sub-Saharan African countries as against the 1,890 kgoe obtainable from developed nations (Abadi et al., 2017; Mungwe et al., 2016; Piker et al., 2017). Another major challenge characterizing the unavailability of renewable energies is poor economic and social development coupled with enormous environmental degradation to alarming state in some communities (Giwa et al., 2017; Ohimain and Izah, 2017; Russo and von Blottnitz, 2017).

African countries are rich in crude oil and this has made fossil fuels the bulk of energy provider across the continent (Canabarro et al., 2013; Liousse et al., 2014). Large deposits of crude oil, tar sands, natural gas and coal abound in some African countries especially in Nigeria (Farooq et al., 2016; Ohimain, 2013). At the same time however, the continent is highly endowed with diverse species of energy-rich plants and other bioresources besides renewables such as hydro, solar, wind and a host of others. There is therefore a regional quest for the generation and sustained distribution of renewable fuels especially over the last two decades (Qi et al., 2005; Rahman et al., 2017; Su et al., 2016). This new drive encompasses primarily fuels from renewable sources and they include biogas, biodiesel, bioethanol and other platform biochemical produced from agricultural, domestic and industrial resources and with the application of simple and indigenous technologies (Mungwe et al., 2016). Of these fuels, biodiesel and especially bioethanol have even been commercialized in some countries and are seen as reliable, abundant, easily accessible and economically feasible renewable energies (Alfa et al., 2014a,b; Schouten and Mathenge, 2010). If well managed, these renewable and clean fuels will improve both agricultural productivity and environmental sustainability across the continent (Estoppey, 2010; Owamah et al., 2014a). Considering the highly dispersed nature of most rural settlements across Africa, grid connection and subsequent electricity supply are technically difficult and expensive (Muller, 2007; Owamah et al., 2014b). This has therefore given the impetus to invest into and disseminate cheap, feasible and decentralized renewable energy facilities into most rural areas (Efeovbokhan et al., 2018). The major challenges with these alternative energies however include huge economic investment and technical know-how considering the low level of human capital development and capacity building in Africa (Rahman et al., 2017).

Generally, energy generated from the above bioenergies are very potent in reducing atmospheric methane emissions (Weiland, 2006). To this extent, many studies have proved the efficiency of the technologies for producing these bioenergy thereby managing organic wastes using an environmental-friendly and cost-effective approach (Cheng et al., 2014; Murphy et al., 2011). Despite huge successes recorded coupled with availability of raw materials and favorable conditions for the generation of bioenergy across many climates globally, African countries have experienced a major setback over the decades owing largely to (i) absence or poor government policies in support of technologies for bioenergy generation, (ii) information deficit on the economic viability of available biomass and waste resources, (iii) lack of technical-knowhow in the design and construction of plants/digesters, (iv) poor or wrong operation and maintenance culture and (v) poor after sale service (Bensah et al., 2010). Besides, there are many other factors affecting the development, promotion and adoption of bioenergy technologies in Africa which include social (Arthur et al., 2011; Katuwal and Bohara, 2009; Nzila et al., 2012), economic (Dahunsi et al., 2017a; Dahunsi et al., 2018a), technical (Dahunsi et al., 2018b; Gwavuya et al., 2012) and organizational factors (Martin et al., 2011). There is therefore need for appropriate government policies and implementation plans toward the adoption of bioenergy technologies across African nations.

Up till now, about $95 \%$ of the populace in developing countries culminating in almost haft of the global population still depend biomass, wood, coal, animal dungs, agricultural residues, and other solid wastes as their primary energy sources (Dahunsi et al., 2019a). To this effect, the World Health Organization (WHO) has arrogated increasing death rate (about 4.3 million annually) and illnesses especially malaria and tuberculosis to indoor air pollution as a result of using these wastes for cooking and heating (Dahunsi et al., $2019 b)$. This is besides the fact that using biomass for cooking is a veritable source of $\mathrm{CO}_{2}$ thereby contributing to the incidence of climate change and global warming alike (Surendra et al., 2014). Therefore, one of the major factors that trap a household into a cycle of illness and extreme poverty is lack of access to modern energy facilities.

To combat this ugly scenario therefore, there should be provision of improved energy systems which includes small-scale bioenergy technology which when implemented will also improve respiratory health of the populace besides combating the menace of climate change (Abila, 2014; Mwirigi et al., 2014). To this effect, many organizations such as the World Bank, the United Nations Secretary-General's Advisory Group which focuses on energy and climate change issues, the Sustainable Energy for All, the East African Community, the United Nations Foundation Global Alliance for Clean Cookstoves, the Economic Community of West African States and the United Nations Commission on Sustainable Development and many other national and international bodies have continually advocated a permanent solution to household energy crisis thereby creating more access to improved energy (Abadi et al., 2017).

Moreover, fostering of human development and the ultimate protection of human and environmental health all hinge on 
unrestricted access to modern energy services. This is without prejudice to the crucial role of quality energy provision will play in achieving the 2030 Sustainable Development Goals (SDGs), most especially goal number 7 which emphasis the provision of affordable and clean energy (Dahunsi et al., 2019, Dahunsi et al., 2019d). When achieved, access to modern energy systems will become an instrumental right to the over 2.6 billion humans' currently lacking access to clean energy and sustainable cooking facilities and who use traditional biomass and other solid wastes as alternatives ultimately leading to ill human and environmental health (Avery et al., 2014; Mandelli et al., 2014; Okello et al., 2013).

\section{Methodology}

All the materials used in this review are research, review and other print and online materials/articles previously published in reputable journals and which have authoritatively reported past and recent trends on the bioenergy status across African countries especially within the last decade. A careful look at these publications showed a lack of concise information on the linkage between the past, current and future achievements and prospects of bioenergy technologies in Africa. This necessitated the sorting and careful compilation of the important information showing the extent of adoption of these technologies in Africa and also to project on the way forward to a robust and environmental-friendly bioeconomic future for the continent hence this review.

\section{The rationale for bioenergy production in Africa}

Most African countries are fast adopting bioenergy technologies and this is because of the urgent need to find suitable alternatives to fossil fuels which is currently the most widespread source of energy. Over decades now, more advanced continents like North and South Americas, Europe and Asia have established commendable levels of research and development in bioenergy production and application. This is largely premised on the understanding that fossil fuels will go into extinction someday. Among the globally embraced energy sources nowadays, fuels generated from diverse bioresources are gaining considerable attention and such fuels have been and will continue to find applications in cooking, heating, as vehicular fuels, in jet engines among many others. It is therefore pertinent for Africa to be integrated into the main stream of bioenergy producing continents and this will engender qualitative societal developments more so that Africa is much blessed with favorable climate, fertile soils, enormous land mass and other environmental-friendly resources which are vital in driving the technology (Romeu-Dalmau et al., 2018). Another major advantage Africa has is population being the most populated continent in the world after Asia and makes up about $10 \%$ of global population (Amigun et al., 2008). This is very vital and have led to the massive consideration of bioenergy mainly biodiesel, biogas and bioethanol as veritable substitutes for crude oil in the continental energy sector (Ohimain and Izah, 2017; Russo and von Blottnitz, 2017; Shane et al., 2017).

Two major steps are involved in bioenergy developments which are (i) creation of required ambience for the actual production of fuels from different resources and (ii) implementing sustainable means of consuming the produced fuels. It is common to see massive bioenergy processing plants across nations of Africa nowadays while the security of energy production and marketing is also being adequately ensured (Dahunsi et al., 2016a; b). Besides, the massive increase in energy consumption across nations of Africa due to sporadic population surge is a yardstick to judge that its time the continent fully embrace the production and sustainable distribution of renewable and environmental-friendly bioenergies mostly from wastes and biomass (Dahunsi and Oranusi, 2013; Dahunsi et al., 2017b, c; Maqhuzu et al., 2017). Research on bioenergy generation has been growing at a slow pace across Africa and the few ones conducted only utilized few of the available resources whereas the very important aspect of evaluating the inherent structural, physical and chemical components of the different biomass and wastes have not been given due attention even though most of them are available year-round. Among the mostly utilized materials for bioenergy research are human and animal excreta, peels of fruits, plant residues and household wastes (Austin and Morris, 2012; Betiku et al., 2016; Nigam and Singh, 2011). Only few succulent plants have been exploited for bioenergy production so far (Alfa et al., 2012, 2013a,b; Saladini et al., 2016).

\section{Bioenergy development in Africa}

Over the last few decades, some significant efforts have been put in place towards the establishment and application of bioenergy technologies across some African countries. This has seen lots of activities executed at individual, institutional, national, regional and international level. However, there seems to still be lots of gaps to be covered in order to measure up to the state of development being witnessed in the Americas, Europe, Asia and even in India Sub-Continent (Bryant and Romijn, 2014). Several reports have highlighted the major problem of the African region to include scarcity or unavailability of suitable bioenergy feedstock due to unimproved agricultural practices (Peterson et al., 2017). A leading bioenergy that has gained wide acceptance in Africa though at a slow pace is biogas as shown in Table 1 . The table shows that very few have installed biogas facilities as a proof of acceptance of the technology as at the year 2005 which is far lower than the situation in other regions of the world (Austin and Morris, 2012). This shortfall led to the launch of a new initiative in 2007 in geared towards the massive installation of biogas plants to the tune of 2

Table 1

African countries with biogas producing digesters.

\begin{tabular}{|c|c|c|}
\hline Region & Country & Number of digesters \\
\hline \multirow[t]{5}{*}{ North } & Egypt & 288 \\
\hline & Sudan & 322 \\
\hline & Morocco & 122 \\
\hline & Tunisia & 60 \\
\hline & & Total $=792$ \\
\hline \multirow[t]{7}{*}{ South } & Botswana & 155 \\
\hline & Lesotho & 50 \\
\hline & Malawi & 9 \\
\hline & South Africa & 322 \\
\hline & Swaziland & 162 \\
\hline & Zimbabwe & 133 \\
\hline & & Total $=831$ \\
\hline \multirow[t]{8}{*}{ West } & Burkina Faso & 2023 \\
\hline & Ghana & 167 \\
\hline & Cote D'Ivoire & 145 \\
\hline & Nigeria & 68 \\
\hline & Senegal & 434 \\
\hline & Cameroon & 179 \\
\hline & Benin Republic & 62 \\
\hline & & Total $=\mathbf{3 , 0 7 8}$ \\
\hline \multirow[t]{8}{*}{ East } & Burundi & 413 \\
\hline & Ethiopia & 5211 \\
\hline & Kenya & 6849 \\
\hline & Rwanda & 2829 \\
\hline & Tanzania & 5280 \\
\hline & Uganda & 3089 \\
\hline & Zambia & 32 \\
\hline & & Total $=23,703$ \\
\hline
\end{tabular}

Source: Abadi et al. [9]. 
million households units by 2020 (Basha et al., 2009; Blanchard et al., 2011; Landi et al., 2013). Three years after this move, about 4,000 biogas plants have been installed across Africa especially in Tanzania but $40 \%$ of these numbers eventually failed because of poor planning and construction, lack of basic community awareness, poor maintenance practice and lack of technical knowledge by users (Graef et al., 2014).

\subsection{Drivers of bioenergy development in Africa}

The 21st-century development is having a great impact on Africa as evident in economic growth and several milestone transformations across the countries. This is beside the ever-increasing human population reputed to have the highest increase rate globally. Perhaps the most obvious phenomenon is Africa's abundant resources that remain grossly untapped and unexploited thereby making the continent a formidable attraction for investment and massive renewable energy development. Besides, the economies of scale have been unlocked and substantial benefits are being offered in various forms including the creation of multiple local value chains, waste management opportunities, innovations in wastewater recycling and water treatment for portability, security in energy provisions and environmental sustainability. Africa currently stands a chance as a major player in the global energy market due to the recent global energy crisis and economic meltdown which has created a platform for showcasing her numerous resources for bioenergy generation across the continent and for export (Avinash et al., 2014; Nigam and Singh, 2011). The other drivers of bioenergy development in Africa include volatile fuel price hikes, utilization of agricultural surpluses, and massive employment creation (Conigliani et al., 2018; Pradhan and Mbohwa, 2014; Scott et al., 2010).

\subsection{Challenges of development}

There numerous challenges preventing the development of bioenergy in Africa most of which are economic, social and security related. These include conflicts with food production, security, prices of commodities, biodiversity loss and environmental degradation as a result of changes in land use. If these issues are addressed and proper bioenergy technologies are implemented, the continent has a great potential for producing bioenergy for both domestic and international markets (Amigun et al., 2011; Ishola et al., 2013; Mohammed et al., 2017; Scott et al., 2010; Tatsidjodoung et al., 2012). In the past decades, there has been a growing interest for bioenergy establishment and expansion in Africa but this has been slowed because of unavailability of sufficient agricultural land for bioenergy production. This equally affected the EU's 2020 plan of meeting 10\% of her transportation fuel needs with renewable energy (Gasparatos et al., 2015).

Besides the above, development and expansion of available bioenergy programs in Africa has been hindered by strong but nonfavorable government policy imperatives and vested interests by different stakeholders ranging from governments at all levels (Local, state, national and international), multi-national agencies, non-governmental organizations (NGOs) to the organized private sector. The effects of these interests are a dictatorship in feedstocks selection and usage with the most contentious ones being Jatropha and sugarcane. Other effects are the feedstock production models i.e. large plantations, smallholder or out-grower schemes and the determination of end uses which in most cases goes into cooking and heating, transportation and electrification, especially at the rural level. Another critical factor limiting bioenergy expansion in the continent is imminent environmental and socioeconomic impacts which include greenhouse gas (GHG) emissions especially methane and carbon monoxide, soil, water, and air pollution culminating in the incidence of global warming and climate change, deforestation and loss in biodiversity. All these factors have become critical in Africa due to lack of sustainable environmental and waste management facilities. Therefore, these factors are of immense magnitude, context-specific and vary absolutely across the different countries (Mungwe et al., 2016). Generally, the major influencers of African bioenergy projects in relations to environment, social and economic status include:

a. Feedstock availability, selection, and efficiency in use,

b. Methods and technologies adopted for bioenergy production and their subsequent usage,

c. The land tenure or usage and the agricultural methods of feedstock production

d. The site availability and selection for bioenergy production purposes,

e. Establishment of the adequate value chain and the life-cycle of the bioenergy,

f. Adequate production and marketing policies

When these factors are viewed holistically, it is reasonable to conclude that bioenergy adoption has performed below expectations in the continent (Atabani et al., 2012). For example, the much proclaimed Jatropha biodiesel project has not been performing as expected in most countries while ethanol production from sugarcane is yet to make an impact despite years of investments. Till now, only few rural households have access to bioenergy for cooking and heating while most people relies on direct burning of local materials and crops residues e.g. maize cobs and plant cereal stalks and animal dung in order to meet their day to day energy requirements. The World Health Organization has estimated that currently, about $85 \%$ of the African populace rely on fuels from direct biomass combustion while $75 \%$ obtains their household energy from wood (World Health Organization, 2000). In this regard, biomass resources for direct combustion may still form the major and easily accessible energy means in the continent. Therefore, the priority areas that require urgent attention if bioenergy projects will stable and sustainable in Africa are:

a. Formulation of favorable policies on bioenergy production as well as alignment regulations for stakeholders,

b. Development of competitive business environments for bioenergy and their allied products/derivatives;

c. Establishment of appropriate expertize in the selection of suitable feedstock;

d. Introduction of high-level technical know-how into the bioenergy sector;

e. Prevention and eradication of unethical and predatory behaviors;

f. Internalization of environmental sustainability mentality in stakeholders in the bioenergy sector;

g. Instituting appropriate land tenure systems and protection in the bioenergy sector;

h. Minimization/reduction in food-fuel competition;

i. Eradication of harmful environmental practices;

j. Promotion of fuels end uses that promote social and environmental benefits.

k. Establishment of appropriate health scheme/policy for bioenergy workers and users

\section{The past decades on bioenergy expansion in Africa}

Over the last four decades, Southern Africa has enjoyed the smooth operation of the sugar industry which stood out as a 
formidable enterprise among the few agro-industries enjoying the suitable climate and this provided a very good competitive advantage over other industries (Gasparatos et al., 2015). This went on successfully with high yield and proceeds until the eruption in bioenergy hype. A similar scenario has been ongoing in Malawi which is among the few countries that in the 80s pioneered bioethanol production from sugarcane molasses for the purpose of transportation in which the produced bioethanol goes into a blend with gasoline at 1:9 ratios. Up till now, the Malawian government has not instituted a legal framework on the blending. Similar sugarcane bioethanol projects were ongoing in Mozambique which gives an indication that the project is cost-effective and suitable for the climatic situation of the continent. However, lots of basic infrastructures need to be in place to foster continuity and profitability of the venture (Blanco et al., 2017).

Malawi pioneered the blending of bioethanol with gasoline on the African continent in 1982 and this grew to be a functional and stable venture setting a pace for other African countries to follow (Johnson and Matsika, 2006). Many countries have since then started numerous bioenergy projects mostly via government sponsorships as the case was in Ethiopia. Others started through the combined efforts of the private sector and individual organizations as evident in the Mozambique bioenergy projects (RomeuDalmau et al., 2018). As this wave swam across Africa, awareness increased tremendously, and the rate of acceptance among the stakeholders and end-users was high mostly due to the potentials of bioenergy to serve as a reliable alternative to fossil fuels which has formed the major source of energy across the countries. Besides, bioenergy stand a great chance in abating environmental pollution due to the constant release of greenhouse gasses from various industrial and processing operations and the transportation sector. To this extent, most African countries dived into the bioenergy business with the motive that the investment will boost their economies, bring about spontaneous developments and alleviate if not totally eradicate poverty. Till now, bioenergy are still receiving significant discussions at the legislature of governments while enormous investments are ongoing in the private sector on the development opportunities for bioenergy (Alic, 2015).

Another major interest of most African countries investment is the struggle to liberate their dangling economies from the overdependence on crude oil business which has reduced the overarching chances of competition and authority. Renewable energies are being seen as a possible replacement for fossil fuels especially in automobiles and other internal combustion engines when used either pure form or blended with gasoline. A bioenergy economy is equally an opportunity to boost agriculture by utilizing the enormous but underutilized arable land across the countries (Tatsidjodoung et al., 2012). Besides, the residues from bioenergy systems can be further processed to form organic fertilizers and soil conditioners with high capacity to increase soil nutrients and beneficial microorganisms.

The international communities are also aware and have taken a strong interest in bioenergy adoption and development in Africa. Enormous foreign investments have been on the increase since 2005 in some Africa countries where the vast expanse of land is acquired for bioenergy production purposes thereby improving the economic situations in those countries. A good number of investors have become major players in African bioenergy projects as they see it to be a lucrative enterprise with high chances of competing in the global fuel/energy markets. Of note are the activities of the European Union (EU) after the EU Renewables Directive 2009/28/ EC (EU-RED) was ratified (Bracco, 2015; Harvey, 2014; Philbrook et al., 2013). In order to meet up with the demand of the EU bioenergy blending program, African feedstock and bioresources are becoming highly valued commodities for export should there be insufficiency in bioenergy generation from European countries (Belward et al., 2012). Another major player apart from the EU is the Southern American bioenergy giant, Brazil with her decision to internationalize the ethanol industry. In this regard also, Africa is a formidable force to reckon with in the area of biomass supplies (Gasparatos et al., 2015; Johnson and Matsika, 2006; Renzaho et al., 2017).

Further, on the international scene, the EU, USA, Canada and Asian giants such as China and Japan have consistently debated the technologies, strategies and best practice options in expanding bioenergy development beyond their borders. Besides many other factors, these continuous moves have been fuelled by the everincreasing issues of environmental degradation accrued to the use of fossil fuels which has led the world to the current ugly menace of global warming and climate change. Other major factors include the quest to strengthen the energy policies, production, and distribution across countries in order to reduce the middle east's monopolistic dominance in the global oil market and to bring stability to prices of fuel/energy (Dahunsi 2019a). In all these, Africa stands the chance of gaining the most as most attention are focused on the continent in order to intensify efforts to raise the awareness and development of bioenergy with the long term benefits of economic and social development.

\section{Africa's electrification; luxury or necessity}

Electricity as a form of energy plays a major role in the development of a nation or continent. The global development in energy and electricity production and distribution has so grown that there are currently less than a billion people without access to electricity. This achievement was made possible by the significant efforts made in the year 2017 the outcome of which saw well over 120 million of the global populace gaining access to electricity. However, Africa has again been left out of this mundane progress while Asia with about the same energy dilemma was able to provide electricity to 375 million of its citizenry between 2011 and 2017. Over the same period, India, Bangladesh, and Indonesia were all able to provide over $80 \%$ electrification rates to their teeming population. Though some levels of improvement have been witnessed in Africa's electrification projects up to about 43\%, the slow pace of development compared to other regions of the world is very worrisome especially due to the ever-increasing human population being witnessed across the African continent. This explains why yet over 600 million African are still living without access to electricity. Perhaps, the massive and continuous population increase and slow electrification process may likely hunt Africa for the next few decades judging by the present situation.

Besides the population, the rate of electricity providers across the different African countries differs at an alarming proportion as shown in Table 2. North Africa nations have been at the forefront in providing access to their citizens as seen in countries like Egypt, Algeria, Morocco, Libya, and Tunisia with over $90 \%$ electrification rate. As a matter of fact, Egypt and Mauritius are the only two countries with $100 \%$ access. In the west, Nigeria and Gabon alongside South Africa belong also have up to $90 \%$ or more while not less 15 other countries have below $25 \%$ access rates. As shown in Fig. 1, 13 countries are still having less than $50 \%$ of their populace lacking access to electricity. The situation is critical in countries such as Ethiopia, Angola, and Sudan which are among the largest economies in the continent and where more people live without access to the power grid. However, East African countries stand out as the least region in terms of electricity access provision (Fig. 2). Currently, Africa's energy comes from different sources (Fig. 3). For Sub-Saharan Africa as a whole, according to the World Bank, sources like coal, gas, hydroelectric, and oil accounts for $38,31,18$ 
Table 2

Electricity rates and accessibility among African countries.

\begin{tabular}{|c|c|c|c|c|c|}
\hline Region & Country & Electricity rates in $\mathrm{kWh}$ & Total population in 2017 & Population without access to electricity & Population without access to electricity (\%) \\
\hline \multirow[t]{2}{*}{ Central } & DR Congo & 11.1 & $81,340,000$ & $12,700,000$ & 16 \\
\hline & Congo & 37.1 & $5,261,000$ & $2,300,000$ & 44 \\
\hline \multirow[t]{4}{*}{ North } & Egypt & 42.0 & $97,550,000$ & 0 & 0 \\
\hline & Sudan & 35.9 & $40,530,000$ & $27,100,000$ & 67 \\
\hline & Morocco & 11.02 & $35,740,000$ & 0 & 0 \\
\hline & Tunisia & 10.0 & $11,530,000$ & 23,060 & 0.2 \\
\hline \multirow[t]{8}{*}{ South } & Botswana & 45.4 & $2,292,000$ & $1,100,000$ & 48 \\
\hline & Lesotho & 16.0 & $2,233,000$ & $1,700,000$ & 76 \\
\hline & Malawi & 9.0 & $18,620,000$ & $12,700,000$ & 68 \\
\hline & South Africa & 9.4 & $56,720,000$ & $7,940,800$ & 14 \\
\hline & Swaziland & 15.0 & $1,367,000$ & 467,651 & 34 \\
\hline & Zimbabwe & 41.5 & $16,530,000$ & $7,300,000$ & 44 \\
\hline & Mozambique & 11.7 & $29,670,000$ & $20,200,000$ & 68 \\
\hline & Namibia & 34.0 & $2,534,000$ & $1,400,000$ & 55 \\
\hline \multirow[t]{9}{*}{ West } & Burkina Faso & 14.6 & $19,190,000$ & $12,600,000$ & 66 \\
\hline & Ghana & 60.5 & $28,830,000$ & $9,400,000$ & 33 \\
\hline & Cote D'Ivoire & 47.3 & $24,290,000$ & $11,100,000$ & 46 \\
\hline & Nigeria & 50.6 & $190,900,000$ & $76,800,000$ & 41 \\
\hline & Senegal & 42.2 & $15,850,000$ & $7,300,000$ & 46 \\
\hline & Cameroon & 48.7 & $24,050,000$ & $10,000,000$ & 42 \\
\hline & Benin Republic & 24.8 & $11,180,000$ & $6,700,000$ & 60 \\
\hline & Togo & 20.0 & $7,798,000$ & $5,300,000$ & 68 \\
\hline & Gabon & 36.7 & $2,025,000$ & 900,000 & 44 \\
\hline \multirow[t]{7}{*}{ East } & Burundi & 5.0 & $10,860,000$ & $10,317,000$ & 95 \\
\hline & Ethiopia & 17.1 & $105,000,000$ & $68,700,000$ & 65 \\
\hline & Kenya & 15.6 & $49,700,000$ & $33,400,000$ & 67 \\
\hline & Rwanda & 51.0 & $12,210,000$ & $8,623,923$ & 71 \\
\hline & Tanzania & 13.9 & $57,310,000$ & $37,700,000$ & 66 \\
\hline & Uganda & 9.0 & $42,860,000$ & $28,100,000$ & 66 \\
\hline & Zambia & 18.8 & $17,090,000$ & $10,500,000$ & 61 \\
\hline \multirow[t]{2}{*}{ Islands } & Madagascar & 19.0 & $25,570,000$ & $15,900,000$ & 77 \\
\hline & Mauritius & 99.4 & $1,265,000$ & 15,433 & 1.2 \\
\hline
\end{tabular}

Source: World Bank [128].

\section{Population without electricity (\%)}

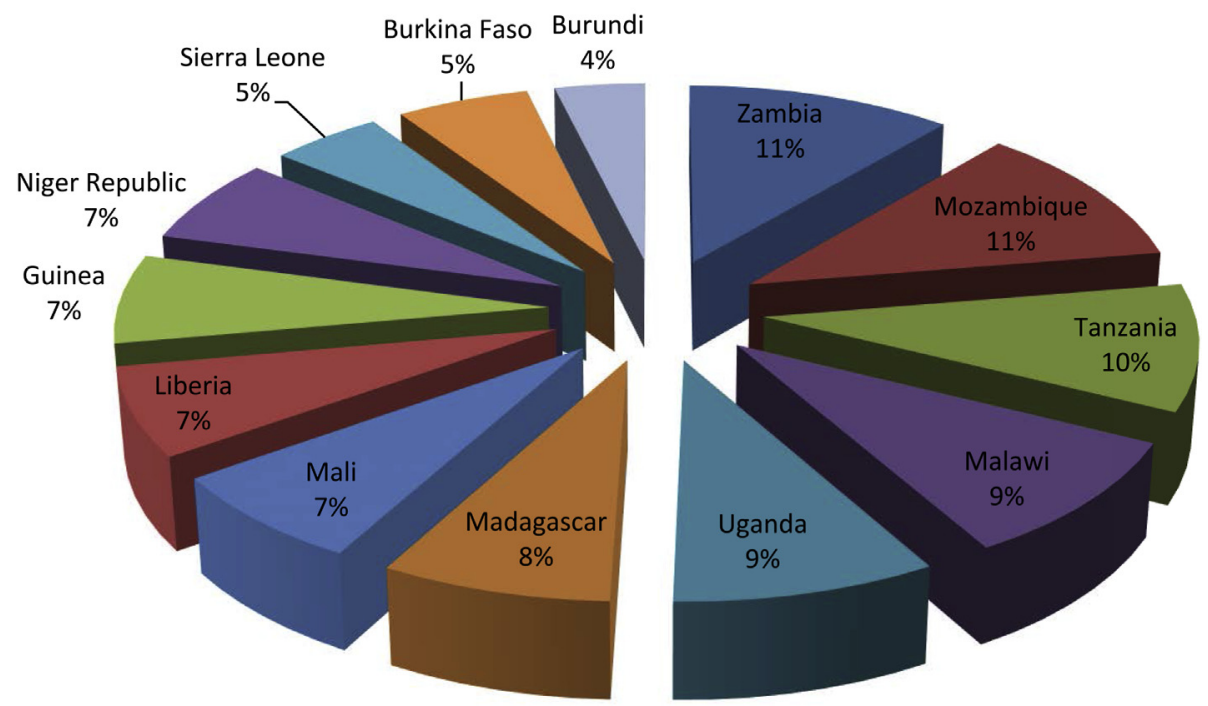

Fig. 1. African countries with majority living without electricity.

and $10 \%$ of electricity supplies respectively. In some countries, however, there are differences e.g. 62\% of Nigeria's electricity is from gas, while $46 \%$ of Kenyan's is from hydroelectric and $19 \%$ from geothermal. In South Africa, 94\% of energy is from coal while the rest is from nuclear sources.

Grid connection has been unsuccessful or slow in most countries due to the high cost and lack of technical know-how. It has been stated that up to an annual investment of $\$ 50$ billion to get 


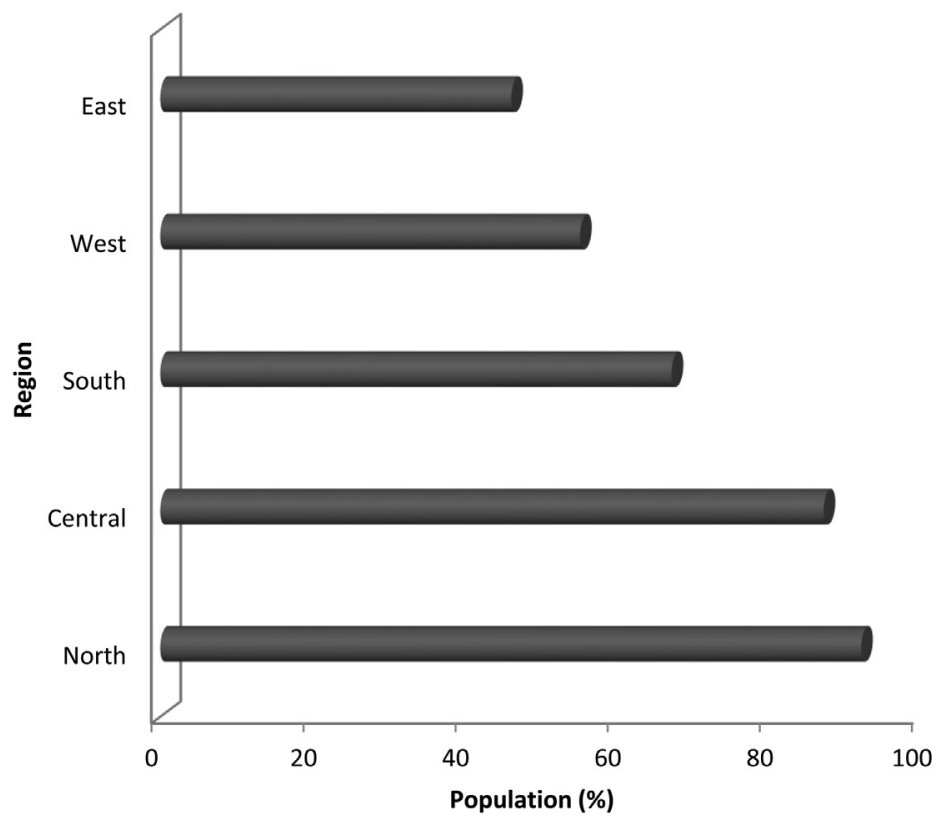

- Population (\%)

Fig. 2. African population with access to electricity by regions.

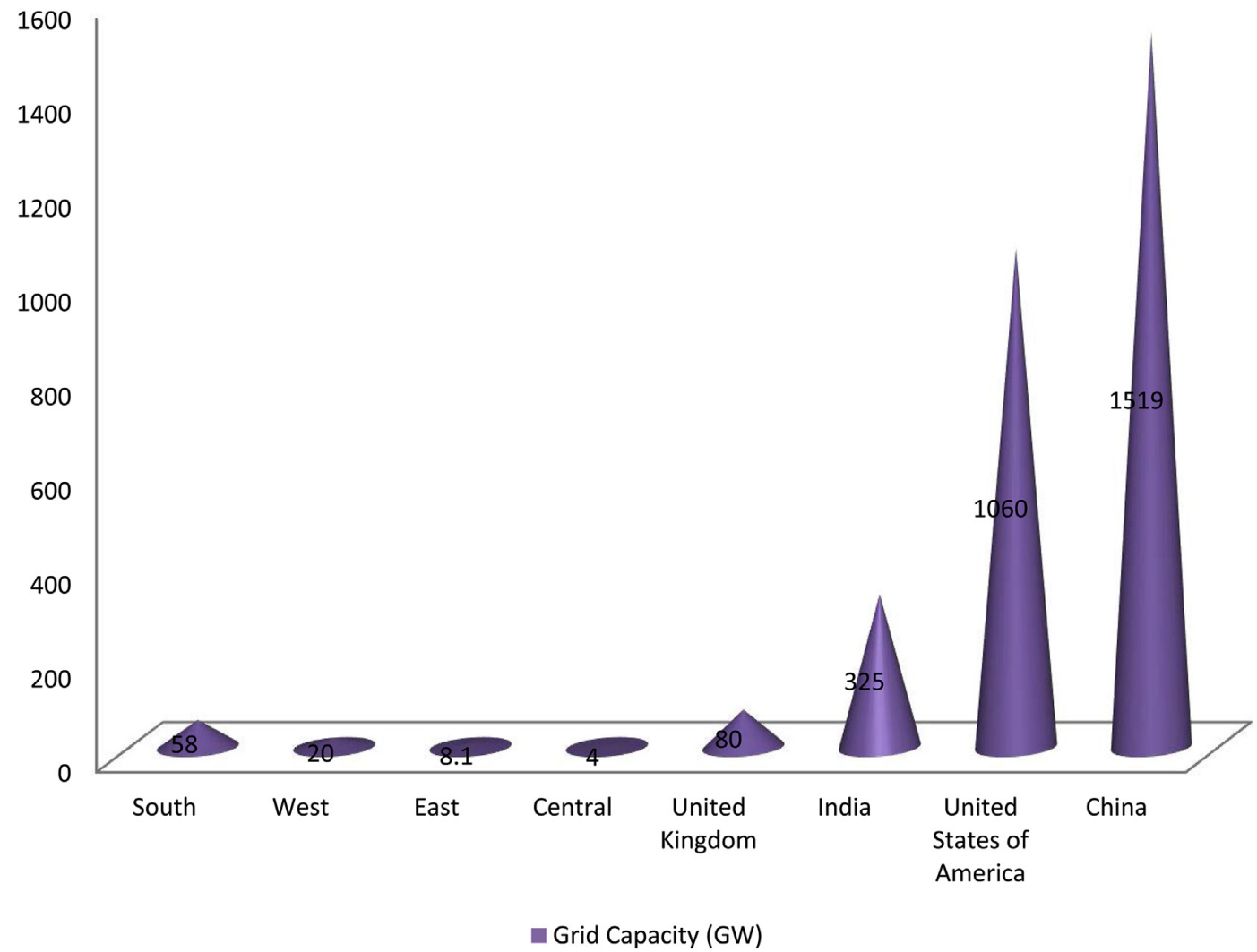

Fig. 3. Power generation output in African regions compared to some developed nations.

Sub-Saharan African countries near the achievement of universal electricity access by 2030 . This definitely has contributed to the hike in electricity tariff. The aftermath of this is constant power outage reaching a total of $4,600 \mathrm{~h}$ annually across Sub- Saharan Africa. This phenomenon has led to the insurgence of massive importation and use of diesel generators which comes with its own attendant challenges of environmental pollution leading to numerous health issues besides the danger of suppressing the local economy through excessive importation (Dahunsi et al., 2017d).

In 2015, Africa could only produce a total of 96 GW (GW) electricity from all installations. When compared with the 80, 325, 1,060 and $1,519 \mathrm{GW}$ generated by the United Kingdom, India, the 
United States, and China respectively (Fig. 4a and b), it is safe to conclude that Africa is still far behind. Nearly half of the electricity generated in Africa is from South Africa (Torretta et al., 2012) while the most populous country, Nigeria, has only succeeded in bringing to the table only a quarter of the South African output. Also, there is a high disproportion between the urban and rural areas in terms of electricity supplies which stands at 71 and $22 \%$ respectively which further confirms the low electricity consumption in the continent (Roopnarain and Adeleke, 2017). Statistics have shown that between 2010 and 2014, the average electricity consumption per capita in Sub-Saharan Africa annually equaled a mere $4 \%$ of the overall United States consumption. This is so because most of the installed grids and their delivery systems are grossly inefficient thereby generating only $40 \%$ of the installed capacity. As important as access to electricity grids is, the actual connection is more important and this is where the major problems of most African countries lie (Fig. 5). Most countries with high access rate perform very poorly in connections and in most cases; connection to the grids is not even a guarantee that there would be a reliable/regular supply of power. Mauritius is leading in the entire continent with high access and connections rates with reliable power supply whereas, Burundi has low access rates coupled with low levels of reliable supply. The situation in Nigeria is critical because a country with 90 and $96 \%$ access and connection rates respectively have a very low $18 \%$ reliable power supply rate. In Tanzania however, $23 \%$ of the citizenry has electric grid connection resulting in supply of power at 54\% reliability. This clearly shows that though the power/ energy crisis may be similar across African states, a diversified approach will definitely be needed to proffer the appropriate solution to each.

As it is, one sure way to remedy the African energy dilemma is by investing in renewable and sustainable sources of energy as this will complement the quantity obtained from the grid. In East Africa, the low development of electricity projects has ignited a surge in investments in alternative renewable energies especially with solar technology leading the way in the region. An important example is a Start-up company called M-Kopa which has been providing solar power solutions for Africans without access to grids or reliable power supply in a low-cost pay-as-you-go manner. The operational target of M-Kopa was to provide power to a million African homes by 2017 with a $\$ 19$ million fund made available. Prominent among the countries leading this renewable energy revolution is Kenya with over $40 \%$ of its electricity coming being generated from renewable sources. Ethiopia has instituted a National Electrification Project meant to provide electricity to the entire populace by 2025 , and $35 \%$ of these energies would come from renewable sources. In the Moroccan scenario, a target of 52\% national energy usage is being planned to come from renewable sources by 2030 (Session Thirteenth and Centre Vienna International, 2009). Similarly, Gabon and Swaziland have grown their electrification projects rapidly in which the access rates have increased by more than $50 \%$ between 2000 and 2016. In the last few years, various renewable energy projects across Sub-Saharan Africa have attracted investments of over 25 billion US dollars. This is besides the African Union's announcement of a whopping 20 billion US dollars investment into renewable energy in Africa. Thus, renewable energy is the future of Africa.

\section{The present bioenergy developments in Africa}

Several African countries have witnessed an upturn in the interest and investments into bioenergy projects in the last few years most of which are currently ongoing and with high promise of enormous growth to comparable global levels. Several bioenergy crops are currently being cultivated in large plantations with the sole aim of bioenergy production and most of which are being properly managed thereby helping to reduce importation of fuels and bills reduction. With the current rate of development, it may not be too far away before bioenergy commercialization becomes a household business in Africa (Amigun et al., 2011; Blanchard et al., 2011; Gasparatos et al., 2015). The major factors that have recently led to this upsurge includes recurrent hike in oil prices caused by uncertainties in government legislation and politics of ownership, numerous environmental degradations caused by fossil fuels,

\section{Quantity (\%)}

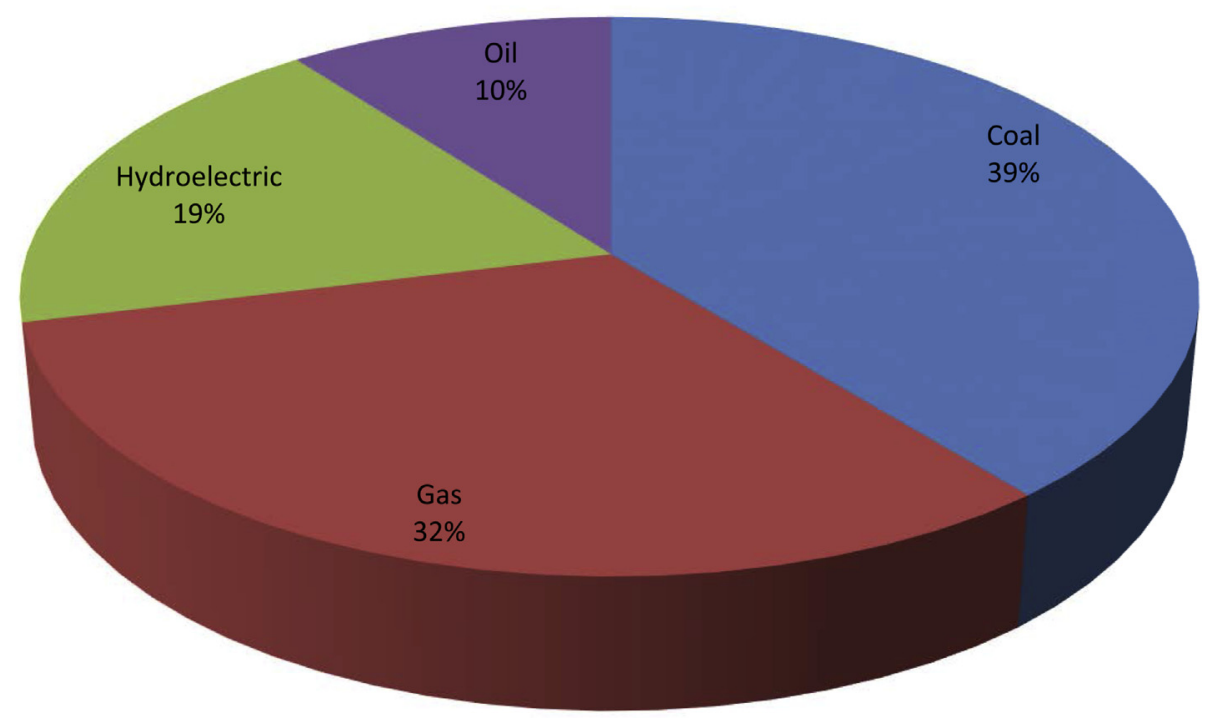

Fig. 4a. Top sources of energy generation in Sub-Saharan Africa. 


\section{Quantity (\%)}

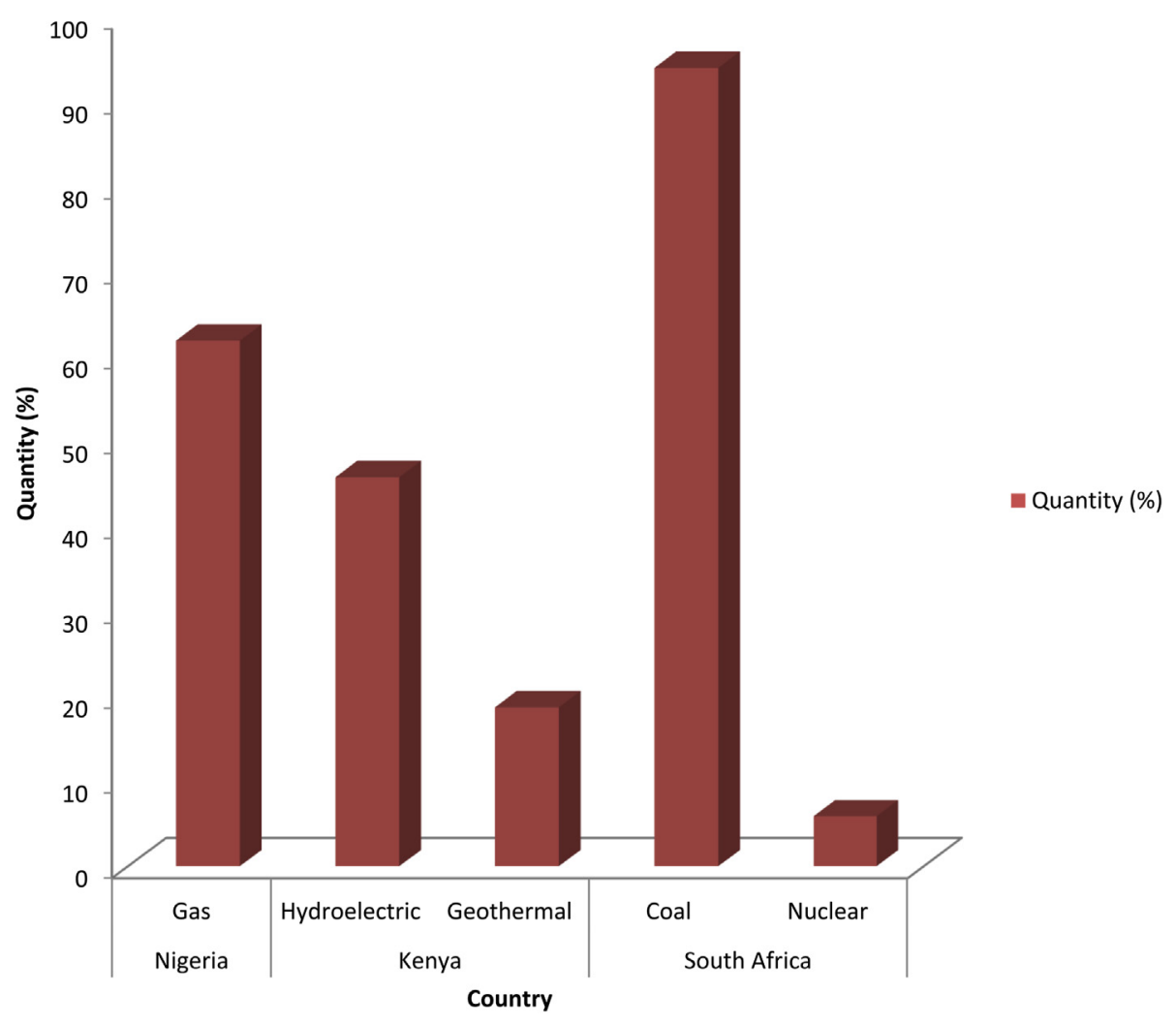

Fig. 4b. Top sources of energy generation in Selected African countries.

availability of massive arable land for cultivation of energy crops, increased in bioenergy research and technological innovations due to access to international funding, potential job creation and economic development, and above all, the quest to fulfill the mandate of providing unrestricted access to energy for the population in alignment to the Sustainable Development Goals (SDGs) (Amigun et al., 2011; Roopnarain and Adeleke, 2017). In reality, African countries are becoming the major suppliers of feedstock to Europe in order to meet the 2020's 8\% market share of bioenergy target by the EU for which unavailability of arable land for energy crops production and the strict guidelines on forest and land use are major challenges in Europe (Belward et al., 2012; Guo et al., 2015).

In light of the above, Africa is currently the continent with the largest capacity for global energy crops production and supply. Many international agreements have been signed by several African nations involving foreign investors who are interested in acquiring massive hectares of arable land for the sole purpose of bioenergy production (Session Thirteenth and Centre Vienna International, 2009). However, one area that requires urgent attention is the establishment of standard policies and regulations guiding these operations. This is necessary to safeguard negative occurrences such as deforestation and loss in biodiversity, reduction in the availability of land for food production and contentions over land which may breed into civil disruption if not carefully handled. Well established policies are only available in very few African nations on the development and sustainability measures for the bioenergy sector (Amigun et al., 2011).

As these new investments promise good better opportunities and fortune in value chain development, several initiatives are ongoing across many African countries on the production of bioenergy at the commercial level. Subsequently, this has caused a sporadic increase in the numbers of large-scale mechanized agriculture in several cropping systems targeting feedstock plantations for bioenergy production. However, most of the machines used are still fuelled by fossil fuels while soil fertility improvement is based on the use of chemical inorganic fertilizers and pesticides for pest control. All these are poised to change as the bioenergy expansion programs thrives more and able to generate enough biomass for bioenergy while the digestates or residues are further processed to liquid and solid biofertilizers and soil conditioners thereby reducing cost while gaining more social and environmental benefits (Janaun and Ellis, 2010). As this investment in sustainable bioenergy production increases, more investment in Africa's neglected agriculture will be stirred up alongside other benefits such as poverty alleviation or reduction, food boom via increased productivity and energy availability and diversification. This also calls for favorable government policies in order to create an enabling ambiance for operations and its sustainability in the long run (Kamp and Bermúdez Forn, 2016). Few countries are already on the right path in providing such policies. A veritable example is the Ethiopian government's sustainable bioenergy development declaration in the capital city of Addis Ababa in August 2007 which is still very much talked about as the very first organized African seminar of bioenergy. At the conference, issues on policy development and decision making on bioenergy development were discussed and this has since set a good place for such discussions and investment justifications across the continent (Dahunsi et al., 2017b; Das, 2017). Another major issue of discussion in bioenergy 


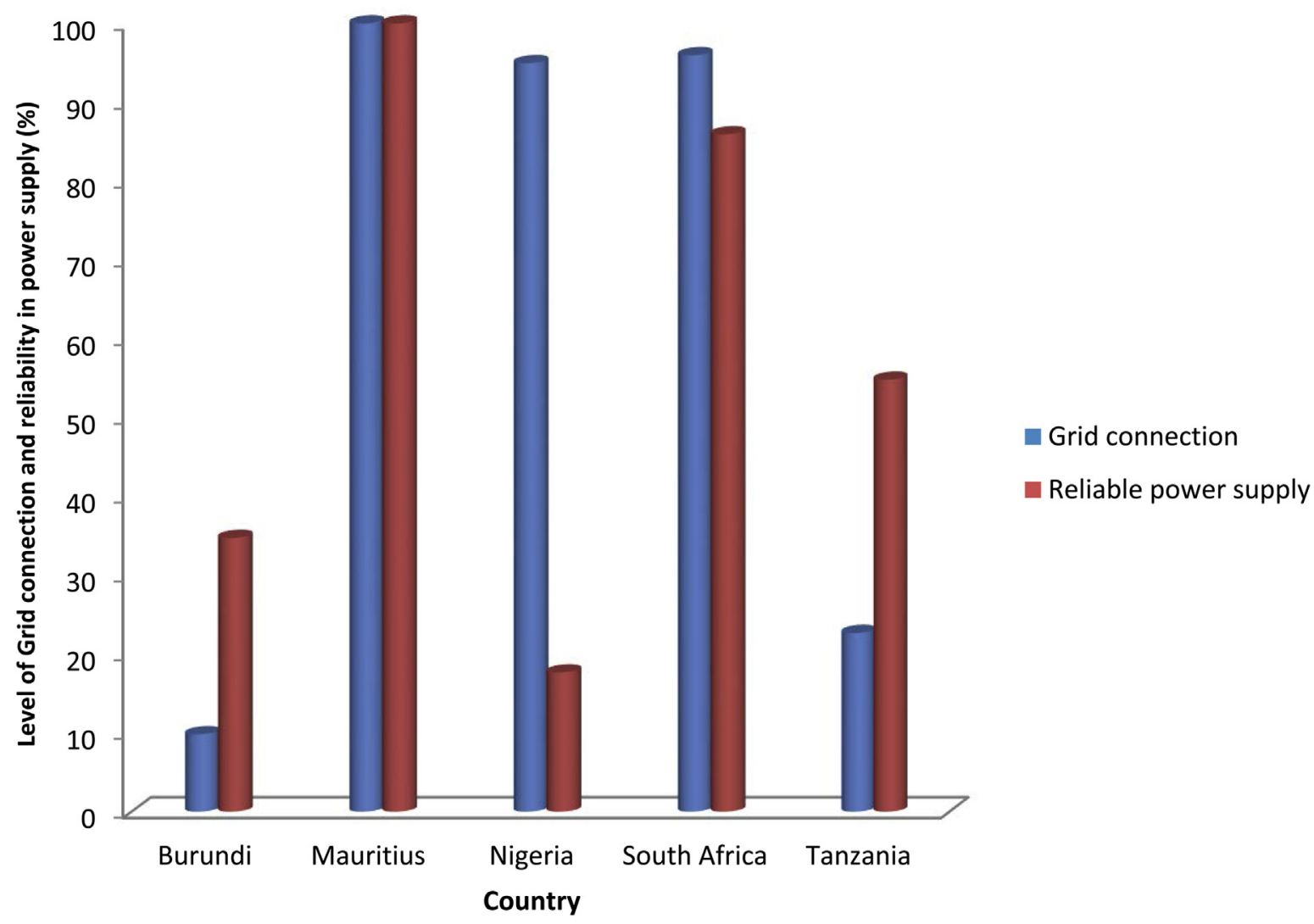

Fig. 5. Disparity in grid connection and reliability in power supply across selected African countries.

development in Africa is sustainability of the process in terms of the production or processing impact, available markets, and the end usage all of which must be critically analyzed with an integrated approach especially based on the three interlinked sustainable development criteria which are the social well-being of the populace, impact on the environment in terms of quality and the economic viability/feasibility of energy production from biomass (Herrmann et al., 2018).

The bioethanol boom started in 2011 with an estimated ethanol production of $145 \mathrm{ML}$ from Africa accounting for $0.17 \%$ of production globally (Giovannetti and Ticci, 2016). Similarly, the year 2007 witnessed the installation and commissioning of the first large scale biodiesel plant in Zimbabwe which though as at 2009 operated at less than 5 percent of its full capacity owing to a shortage in availability of feedstock materials (Jumbe and Mkondiwa, 2013; Kamp and Bermúdez Forn, 2016). However, the situation has since changes as both bioethanol and biodiesel are now produced in commercial quantities in many countries thereby still creating more opportunities for investment. Africa boasts of the largest share of global non-protected grassland, woodlands and tropical rain forest which is highly suitable for growing of bioenergy feedstock plantations especially for crops like Jatropha, sugarcane, maize, cassava, soybean, etc. Besides, large portions of currently cultivated land mass across Africa are still potentially useful for the cultivation of energy crops (Bryant and Romijn, 2014). These facts are obvious to international investors most of whom have been investing heavily in massive land acquisitions for the sole purpose of bioenergy projects thereby increasing the rate of success of the program as evident from the reports of the Land Matrix Global Observatory. The Sub-Saharan region of Africa is the richest in bioresources and houses between 40 and 50 percent of global deals for crops and plant residues suitable as bioenergy feedstock beside having the greatest land mass acquisition by international agencies through various collaboration efforts over the last decades (Aha and Ayitey, 2017). The success of these operations brings enormous opportunities by eliminating the natural risk of overdependence on traditional unprocessed wood and agricultural biomass as the main energy sources across the continent with attendants negative consequences such as health challenges, excessive workload by women and children, coupled with untold environmental decadence (Saladini et al., 2016). The injection of bioenergy to replace them is being seen as new technology capable of better carbon utilization because they are renewable. The application of these renewable fuels is gradually increasing across the continent as liquid bioenergy are now blended for use in the transportation sector without necessarily changing the existing infrastructure and has also made them suitable candidates for use in cooking, lighting, and generation of electricity (Alfa et al., 2013a,b; Dahunsi et al., 2018c). In recent years, some major developments in bioenergy adoption in some African countries as shown below:

\subsection{Nigeria}

Nigeria is undoubtedly the most populous country on the African continent with an abundance of human and natural resources. However, energy remains a major mirage in the quest of the country to attain developments. About $70 \%$ of Nigerians depends solely on firewood combustion for their daily energy needs (Ishola et al., 2013). The aftermath of this phenomenon is increased deforestation, the highest the world over (Alfa et al., 2012; Mulugetta, 2009). The most embraced bioenergy so far in Nigeria over the last few decades is biodiesel majorly because of the 
abundance of Jatropha curcus plantations across all geopolitical zones of the country. Several research efforts have gone into the biodiesel project using several fruit seeds and waste materials and these have resulted into several fuel blends that have successfully gone through trials in internal combustion engines with high potentials of replacing fuels of fossil origin in the automobile and manufacturing industries among others (Betiku et al., 2016; Dahunsi et al., 2017e, f; Mahmudul et al., 2017). It is needless to say that Nigeria is extremely rich in biomass, forest residues, nonedible seeds and waste resources enough to keep the biodiesel project functioning on a continuous scale. However, only very little attempts have been made to commercialize the biodiesel technology and this has seriously militated against its development on a significant scale (Ishola et al., 2013). Another bioenergy that is currently making waves in Nigeria is biogas. As a matter of fact, anaerobic digestion technology seems to suit the country situation better due to its low-cost and ease of operation. Perhaps, the major advantage for the biogas technology adoption in Nigeria is the availability of sunlight which provides maximum heating for the digesters especially at the mesophilic range and even thermophilic in some regions e.g. upper Northern Nigeria (Alfa et al., 2014a,b; Dahunsi et al., 2018b; Zahedi et al., 2018). Generation of biogas stands out as a veritable option with numerous benefits, especially in the reduction of health hazards, contamination of indoor air and deforestation which is fast becoming a serious issue of concern in the country. However, most biogas production efforts have been as it is, more than $40 \%$ of the populace lives in rural areas where firewood is the major source of heating, cooking, etc. This technology has the much-needed capacity in Nigeria to anaerobically convert the annual 545 million tons of organic municipal wastes produced in the country to well over 28 billion $\mathrm{m}^{3}$ of biogas and this can, in turn, generate up to 173,458 MWh electricity. This biogas can be the basis for grid decentralization for ease of energy access to all regions and especially the rural areas. Besides the biogas energy, there is the potential for producing more than 90 million tons of organic fertilizer from the wastes alone besides diverse biomass and animal wastes in abattoirs and farms spread across the country (Roopnarain and Adeleke, 2017). In the course of time, the Nigerian bioenergy industry has equally received a boost with the upsurge and huge investment in bioethanol production. Currently, Nigeria is investigating the opportunities in developing a robust local and international "cassava economy" majorly for the purpose of ethanol production. This has seen a massive movement of farmers and entrepreneurs into the cassava value chain and several out-grower schemes across the nation making ethanol a veritable potential fuel for transport with a high value on the market (Giwa et al., 2017).

\subsection{South Africa}

South Africa occupies a very strategic position in the African energy mix as a nation that single-handedly consumes about $45 \%$ of the continental energy generation most of which are internally generated within the nation (Russo and von Blottnitz, 2017) courtesy of the state-owned Energy Supply Commission (Eskom). The country has through this company generated her energy from coal combustion (Blanchard et al., 2011; Singh, 2006). This excessive reliance on fossil fuel has since made South Africa the number one GHG emitter in Africa and undoubtedly prominent among the global top 20 (Aliyu et al., 2018). This phenomenon has since called for eco-friendly and sustainable alternative energy generation. In this quest, anaerobic digestion for biogas generation has been at the forefront in the nation for some decades now. Recently, the biogas potential of the nation has been estimated to be able to generate up to $2.7 \mathrm{GW}$ of electricity with a whopping $\mathrm{R} 11$ billion potential in the market coupled with the creation of jobs in thousands (Hagos et al., 2017). With these facts, the number of working biogas plants has been on the increase especially since 3013 when the first South African Biogas conference was held (Blanchard et al., 2011; Liousse et al., 2014). Besides, numerous South African-based organizations and institutions have been doing a lot in biogas-related research and implementation programs which informed the installation of more functional digesters across the country, especially in Johannesburg and Pretoria. The government has also made significant investments especially through its Renewable Energy Independent Power Producer Procurement (REIPPP), focusing on solar energy research. An increase in nuclear capacity is also on the agenda.

\subsection{Burkina Faso}

Judging by the ever-increasing energy demand, usage, and price volatility, the Burkina Faso government has committed itself into reasonable massive investment into bioenergy production with a stable policy for sustaining the project. This commitment was made public at the capital city of Ouagadougou in 2009 during the International Bioenergy Conference (Tatsidjodoung et al., 2012). In the policy, the government puts an upper benchmark for lands which are meant for energy production at a fixed 500,000 ha which corresponds to $5 \%$ of the total arable land. Also, the policy promotes the involvement of traditional peasant farmers as stakeholders in the supply of raw material meant for local generation of bioenergy to be sold within the domestic market. The major crop of focus in this policy development is Jatropha curcas and several incentives are provided to encourage the participation of more local farmers in the scheme. Accompanying the policy are standard regulations on tax in order to maximize the economic benefits derived from substituting fossil fuels with a bioeconomy. These include savings in foreign currency earnings, value addition to local and national markets, and majorly to promote the rural economy.

In another recent development, the Burkina Faso government has instituted a global plan to reduce poverty in the nation while targeting human and capital economic growth (Hanff et al., 2011). The plan includes strategies for economic competitiveness, and its adequate integration into the global economy with the long term agenda of improving the wellbeing of the nation as a whole. Across Burkina Faso, bioenergy technologies are being massively embraced for developmental sustainability due to reasons such as energy security and access, capacity for environmental protection, savings in foreign currency, among many other socio-economic issues paramount in the rural areas. So far, bioenergy production has significantly brought many macroeconomic advantages to the country as evident by the balance of trade deficit reduction, direct and indirect increase in GNP via impacting on the economy as well as improvement in living standards (Roopnarain and Adeleke, 2017).

\subsection{Mali}

Mali has also recently developed numerous functional bioenergy programs which majorly depend on the local dwellers and farmers for raw materials supplies. An outstanding example is a local Non-governmental organization called "Mali-Folke Centre" with the business of providing incentives and support to local farmers for Jatropha cultivation geared toward oil production. With the huge Jatropha biomass turnout and its subsequent conversion to oil, electricity is constantly being supplied to all settlements within a $20 \mathrm{~km}$ radius from the operating center. Leveraging on the success so far, the center has recently embarked on the electrification of well over 10,000 residents in rural areas in South of Mali by launching the operation of a $300 \mathrm{KV}$ power plant that will run for 
15 -year on a commercial scale. For this purpose, 1000 ha of Jatropha plantation is cultivated for provision of biomass to feed the plant (Mulugetta, 2009). Definitely, this project is poised to bring massive transformations and developments to the lives of the residents in these areas by the provision of the electricity.

\subsection{Tanzania}

Tanzania is currently witnessing massive transformations from a fossil-based economy to a bio-based one owing to the relentless efforts of numerous multinational companies, NGOs and smallholder farmers. There has been a sporadic increase in the liquid bioenergy production and supplies to the masses. Besides, Jatropha plantations and those of other high-yielding energy crops are being established in different parts of the country via the investment of well over ten companies who successfully acquired massive land mass for the purpose (Atabani et al., 2012; Demirbas, 2005). Some of these companies are American-based e.g. Prokon, Wilma, SEKAB, and Diligent while others are from Europe and specifically the United Kingdom, Germany, and the Netherlands. Other firms have instituted strong collaborations with local Tanzanian organizations to produce bioenergy. These include the Program for Biomass Energy Conservation and the Southern Africa Development Community which have implemented several biomass cultivation projects so as to make biomass available for bioenergy production and its improved supply to the masses. Another prominent firm is the Belgium-based which focus on growing biomass for energy to better the livelihoods of the citizenry. Local NGOs are not left behind in the bioenergy race in Tanzania as many of them are equally instituting numerous bioenergy projects in the rural settings (Rupf et al., 2015).

\subsection{Ghana}

The game plan in the Ghanaian bioenergy industry has changed sporadically from the initial energy security promotion through smallholder-based projects to its current promotion of rural development via the activities of the "Farming Development Initiatives" (FDIs) with the utmost aim of exporting produced bioenergy to the international markets (Ahmed et al., 2017). However, the Ghanaian bioenergy program is currently suffering a major setback due to reasons as (a) the discontinuity in almost all the once thriving Jatropha plantations, (b) non-favorable government policies on bioenergy, and (c) non-availability of functional local bioenergy market or exports. The Ghanaian Jatropha projects failed majorly due to multiple interrelated factors paramount among which was crude oil discovery (Mulugetta, 2009), political instability and lack of government commitments to the project. However, there are huge potentials for improvements and efforts are being made in several sectors of the Ghanaian economy to revive the success of the bioenergy boom of the mid to late 2000s which was characterized by major discoveries in agronomy, land allocation, land administration and commercial-scale acquisition reforms, and suitable consensus/agreements between local and national authorities for smooth investments in bioenergy developments. This surely has strong potentials to enhance the longterm sustainability/viability of the bioenergy sector.

\subsection{Zimbabwe}

Zimbabwe is perhaps one of the least developed countries in Africa characterized by massive importation of goods and resources including her oil needs. However, recently in 2013, the country instituted a policy of blending $10 \%$ bioenergy by the year 2017 (Ewing and Msangi, 2009). The prerogative that informed this decision was the mass availability of suitable arable land located in favorable agro-ecological zones in the country and which could be effectively utilized for the cultivation of energy crops especially Jatropha (Avinash et al., 2014). Due to land tenure issues however, the execution of the bioenergy projects in Zimbabwe now relies on the aptness of specific sites of bioenergy for the entire country as well as to the locality (Maqhuzu et al., 2017).

Presently, several countries in the African continent have established bioenergy policies but only that they don't have coherent overall strategies yet. However, it's also been established that South Africa championed the crusade on bioenergy development and expansion in Africa with the installations of modern plants for commercial production and was also the lead among countries to formally implement a bioenergy action in 2007 after which Mozambique did hers in 2009 (Jumbe et al., 2009). Rural income sources diversification, creation of employment, energy security improvement, drastic reduction on oil importation, earning of foreign currencies from bioenergy exports, and GHG emissions reduction are the positive effects (Giovannetti and Ticci, 2016), however, there are many risks involved. Expansion of bioenergy projects can increase competitions and pressures on the sustainable use of water, land, and forests but only regions with weak or non-existence land tenure systems. Bioenergy could also exert enormous pressure on prices of food but this could easily be surmounted by a well-developed biomass production and waste management systems (Das, 2017). In the area of carbon balance, a well-planned bioenergy system is capable of GHG emissions mitigation as the gasses that would have been emitted into the environment are captured for sustainable usage in different forms (Dahunsi et al., 2017b, c; Semwal et al., 2011).

As it is, bioenergy development has a huge potential to offer numerous promises as well as a few challenges for developing countries in Africa (Blanchard et al., 2011). While a school of thought believes that production of bioenergy is a major threat to food supplies especially for the rural poor, another solid opinion is that the development of the bioenergy can be a productive and profitable adventure with high stimulation of rural economies in developing nations if properly managed. The situation is potent enough to increase the energy crops demands including sugarcane, soybeans, rapeseed and oil palm usually cultivated by the local farmers. Besides, abandoned and marginal lands that are no longer ideal for crop plants cultivation could be utilized for Jatropha curcas cultivation as a way of increasing farmers income. It is also been debated that with high level technology in place, modern biorefineries could also be useful in the provision of extra income for developing country farmers via the sales of plant wastes and residues that can be converted into biogas, ethanol and can further be processed to produce electricity.

The coming decades will definitely witness a massive increase in the demand for biomass for energy generation globally. The recent United Nations (UN) reported that global bioenergy production has doubled in the last 5 years and will yet double again in another 4 years (Chirambo, 2016; Dahunsi, 2019b; Jagadevan et al., 2018). Moreover, the economies of African countries are currently growing at $4 \%$ rate per year on the average while Sub-Saharan Africa produced 6 fastest growing economies among the 10 best globally in the last decade. At this rate, the GDP of Africa would have tripled by 2030 and 7 fold by the year 2050. Therefore, the sustenance of this growth will only be sustained by very stable and progressive energy system influenced by a functional energy policy across the continent (IRENA, 2013).

Currently, an estimated $590,000,000$ persons which are $57 \%$ of the Africans continent lives without access to electricity while a whopping $700,000,000$ making a total of $68 \%$ of the population) lives without access to sustainable energy cooking facilities 
(Roopnarain and Adeleke, 2017). With the current trend in energy access, a total of $655,000,000$ (42\%) Africans will still lack access while $866,000,000$ (56\%) will still be without clean cooking facilities come the year 2030 which means that these majority of the population will still be deprived the opportunity to lead a decent and productive lifestyle. Though bioenergy projects have been ongoing since 2007, there has also been implementation hiccups majorly because of poor political systems or will couple with prevailing food insecurity menace (Simpson, 2009) are posing threats to the development. Farmers who are major producers of maize have been agitating against the non-inclusion of maize as a feedstock in the bioenergy mix in the continent. However, the exclusion is necessary as maize serves as one of the leading staple food for the African population and its usage for bioethanol production will only heighten the food versus fuel saga. This explains why more attention has been given to second generation bioenergy technologies with the focus on agricultural residues, animal dung/droppings and wastes resources for bioenergy production.

Bioenergy feedstocks are majorly from agricultural sources with high commercial production potentials in order to provide many economic benefits directly to rural households and the nation at large. Save for a few project types, feedstock cultivation should be regarded as cash crops farming. In this regard, feedstock production is an important strategy for modernizing agriculture across Africa having tangible effects on the economy of nations leading to poverty alleviation (Kgathi et al., 2017). Macroeconomic studies (Arndt et al., 2011; Hanff et al., 2011), has equally revealed that massive investment and subsequent expansion in bioenergy projects is a potential route to economic advancement in countries such as Mozambique and Tanzania. A general equilibrium modeling (GEM) study has earlier revealed that bioenergy production has the capacity to increase the gross domestic product (GDP) of Mozambique by approximately $0.37 \%$ besides the generation of 271,000 jobs for the rural populace (Arndt et al., 2011). Similarly, a GDP increase by $0.25-0.37 \%$ is feasible for Tanzania coupled with a significant generation of employment. These gains, however, depend on the types of technology adopted for bioenergy production as experience has shown that smallholder and out-grower systems are absolutely the best in terms of national economic growth (Arndt et al., 2011).

\section{Bioenergy feedstock in Africa}

For Africa to become successful in the adoption and implementation of bioenergy technologies, there must be a program to careful identify and select suitable feedstock for fuel production. Globally, diverse types of feedstock have experimented for fuel production and these include different food wastes, agricultural residues, different energy crops, solid wastes, wastewaters/sewage and wastes from municipalities among others. In this respect, diverse economically viable and indigenous bioenergy feedstocks have been selected. Some of these are aquatic plants, wastes and residues from agricultural practices, industrial and processing wastes, domestic refuse and sewage and municipal wastes (Dahunsi et al., 2016b; Shane et al., 2017). This is beside constant efforts been made to adequately identify other indigenous biomass for bioenergy generation (Singh, 2006). Besides, aquatic plants, few other biomass such as leaves of Manihot esculenta, Eupatorium odoratum and Cymbopogon citratus (Alfa et al., 2012; Dahunsi et al., 2017b), and shoots of Tithonia diversifolia, Chromolaena odorata (Dahunsi et al., 2017a; Murphy et al., 2011) have been used. Others are fruit rind of Carica papaya, Telfairia occidentalis and pod hulls of Arachis hypogaea and Theobroma cacao among others (Alfa et al., 2013a,b; Austin and Morris, 2012).

Most of the above-named biomass has also been co-digested with animal droppings in order to enhance the carbon and nutrient balance thereby increasing biogas yield. In a previous study, the co-digestion of banana and plantain peels (Dahunsi et al., 2018a) was carried out while that of piggery dung and Manihot esculenta peels seeded with wood ash was experimented and the biogas yield increase was significant (Alfa et al., 2013a,b). Biogas has also been efficiently generated from fruit shells of Lophira lanceolata (Rupf et al., 2016). In this regard, indigenous algal species are not left out as they have been explored for biogas production (Nigam and Singh, 2011). Hagos et al. (2017) compared the biogas production from Eupatorium odoratum, water lettuce, water hyacinth, and cow dung and reported the highest biogas yield from that Eupatorium odoratum while the least was obtained from cow dung (Mungwe et al., 2016). Biogas generation from cow dung, poultry manure and abattoir wastes have also been carried out (Alfa et al., 2014a,b; Mungwe et al., 2016).

\section{Future of bioenergy development in Africa}

Bioenergy hold the key to unlock the energy and economic future of Africa if well planned and executed. The quest to sustain the current economic growth across the continent will only be a reality if a larger and better performing energy sector is executed (IRENA, 2013; Sikarwar et al., 2017). The International Renewable Energy Agency (IRENA) has instituted a robust renewable energy scenario for Africa in which the impacts of all existing policies meant to drive the execution of bioenergy projects up till 2030 were critically examined. There is a projection that renewable energies could increase from $17 \%$ in it was in 2009 to $50 \%$ in 2030 , and then to $75 \%$ by 2050 . This implies that there must be a consistent growth in the total installed capacity for renewable energy generation from $28 \mathrm{GW}$ in 2010 to $800 \mathrm{GW}$ by 2050, out of which solar photovoltaic, wind power, hydropower, concentrated solar power, biomass, and geothermal sources will account for $245,242,149,94$, 69 and 8 GW respectively.

Several factors need be considered before lands for biomass cultivation are acquired and these include the biomass type, geographical location, financial inputs and the target yield from planted crops (Guzatto et al., 2011). Projections have been made that up to a conservative $166,000,000$ ha of land will be required to grow biomass by 2020 in the absence of new bioenergy policy promotion. It has also been projected that between 118 and $508,000,000$ ha will be needed in order to provide $10 \%$ of the energy demand in the transportation sector globally which will further demand that between 144 and 334,000,000 ha of additional land will be required for food production by 2020 . This further shows that attention will soon need to be focused on abandoned and marginal land and the African continent so a vast array of these thus making her a future major player in the global bioenergy market (Ahmed et al., 2017; Gasparatos et al., 2015; Qi et al., 2005).

Currently, about 388 EJ/annum of energy is consumed from fossil origin which must increase so as to meet the demands of the population. It is possible to increase this to $400 \mathrm{EJ} / \mathrm{annum}$ by 2050 (IRENA, 2013). There are short term projections that technological conversion of biomass and waste resources will contribute up to 68 $\mathrm{EJ} / \mathrm{annum}$ to the global energy grid by 2030 . It is easier to integrate bioenergy production into existing technology without major modification. For example, up to $10 \%$ ethanol blends are possible while $100 \%$ biodiesel usage is possible (Amigun et al., 2008). Besides, numerous biomass and feedstock available with African countries can be utilized for bioenergy generation whereas, crude oil has no alternative. Another major advantage of bioenergy over fossil fuel is in the production in which there are rooms for much technological advancement and innovation for the future production of different bioenergy. However, the petroleum industry seems 
to be well developed giving no impetus for further development (Blanchard et al., 2011).

\section{Conclusions}

This review investigates the past and current status of bioenergy technologies adoption in Africa.

The examination of different research, review and other print and online materials/articles which previously reported past and recent trends on the bioenergy status across African countries is devoid of reliable data linking the past, current and future achievements and prospects of bioenergy technologies on the continent. This therefore led to the compilation of adequate and current information on the technologies adoption in Africa besides projecting the future trends in achieving a continental economy driven by different biofuels and their numerous applications.

The results show that globally, energy production and distribution has received a major boost so much that less than a billion people are now without access to energy especially electricity. This development however did not significantly affect Africa whereas Asia which previously had similar energy challenges got 375 million of its citizenry out of energy poverty between 2011 and 2017. The major beneficiaries of this development were India, Bangladesh, and Indonesia with over $80 \%$ of their populations supplied with electrification. Though, some levels of improvement have been witnessed in Africa's electrification projects up to about 43\% especially in South Africa, Nigeria, Burkina Faso, Mali, Tanzania, Ghana and Zimbabwe. The major challenge is the slow pace of development in comparison with other continents considering the constant increase in human population across African. This explains why yet over 600 million African are still living without access to electricity.

This paper therefore advocate for the inclusion of bioenergy in the African future energy projection due to their immense potentials to transform the continent. Africa stands a chance of becoming a major player in the global energy market. It has also been clearly shown that if fully invested in, bioenergy has the huge potentials to impact on various aspects of life in rural and urban settlements across African countries. It is however important to know that these impacts will largely depend on many factors such as feedstock type, production method, end usage, land tenure policies, access to land for biomass production, availability of sustainable agricultural inputs, site selection for bioenergy production, availability of markets, environmental and socioeconomic considerations, bioenergy production life-cycle assessment impact, and prevailing government/political policies. Thus, reliable bioenergy policies must be in place in respective countries in order to experience the future been shot for in the African bioenergy industry.

If these measures are in place, there will be improvement in human capital development and health/wellbeing thus achieving some of the Sustainable Development Goals (SGDs) e.g. SDGs 1 (Reduction of poverty), 2 (Hunger eradication), 3 (Quality health and wellness), 7 (Clean and affordable energy), 8 (Conducive working environment and developed economy), 12 (Sustainable resource production and utilization) and 13 (Climate protection).

\section{Author statement}

Dahunsi SO wrote most part of the manuscript and serve as corresponding author for the submission. Fagbiele 00 did the thorough search for literatures used in writing the review article. Yusuf EO assisted in the thorough search for literatures and also wrote part of the final manuscript.

\section{Funding source}

This research received funding from the Ton Duc Thang University, Ho Chi Minh City, Vietnam.

\section{Declaration of competing interest}

The authors declare that they have no known competing financial interests or personal relationships that could have appeared to influence the work reported in this paper.

\section{Acknowledgments}

The author appreciates the Ton Duc Thang University, Ho Chi Minh City, Vietnam for providing funds for this research.

$\begin{array}{ll}\text { Abbreviations } \\ \text { Eskom } & \text { Energy Supply Commission } \\ \text { EU } & \text { European Union } \\ \text { EU-RED } & \text { European Union Renewable Energy Directives } \\ \text { FDIs } & \text { Farming Development Initiatives } \\ \text { GDP } & \text { Gross Domestic Products } \\ \text { GEM } & \text { General Equilibrium Modeling } \\ \text { GHG } & \text { Greenhouse Gasses } \\ \text { GNP } & \text { Gross National Products } \\ \text { GW } & \text { Gigawatts } \\ \text { IRENA } & \text { International Renewable Energy Agency } \\ \text { KWh } & \text { Kilowatts hour } \\ \text { MWh } & \text { Megawatts hour } \\ \text { NGOs } & \text { Non-Governmental Organizations } \\ \text { OFMSW } & \text { Organic Fraction of Municipal Solid Wastes } \\ \text { PROBEC } & \text { Program for Biomass Energy Conservation } \\ \text { REIPPP } & \text { Renewable Energy Independence Power Produce } \\ & \text { Procurement } \\ \text { SADC } & \text { Southern Africa Development Community } \\ \text { SDGs } & \text { Sustainable Development Goals } \\ \text { UN } & \text { United Nations } \\ \text { WHO } & \text { World Health Organization } \\ & \end{array}$

\section{References}

Abadi, N., Gebrehiwot, K., Techane, A., Nerea, H., 2017. Links between biogas technology adoption and health status of households in rural Tigray, Northern Ethiopia. Energy Pol. 101, 284-292.

Abila, N., 2014. Managing municipal wastes for energy generation in Nigeria. Renew. Sustain. Energy Rev. 37, 182-190.

Aha, B., Ayitey, J.Z., 2017. Biofuels and the hazards of land grabbing: tenure (in) security and indigenous farmers' investment decisions in Ghana. Land Use Pol. 60, 48-59.

Ahmed, A., Campion, B.B., Gasparatos, A., 2017. Biofuel development in Ghana: policies of expansion and drivers of failure in the jatropha sector. Renew. Sustain. Energy Rev. 70, 133-149.

Alfa, I.M., Okuofu, C.A., Adie, D.B., Dahunsi, S.O., Oranusi, U.S., Idowu, S.A., 2012 Evaluation of biogas potentials of Cymbopogon citratus as alternative energy in Nigeria. Int'l J. Green Chem. Biopr. 2 (4), 34-38.

Alfa, M.I., Adie, D.B., Iorhemen, O.T., Okafor, C.C., Ajayi, S.A., Danhunsi, S.O., 2013a. Assessment of mesophilic Co-digestion of cow dung with lemon grass for biogas production. Nig. J. Technol. 32, 478-484.

Alfa, M.I., Otun, J.A., Igboro, S.B., Dahunsi, S.O., Ajayi, S.A., Akali, D.M., 2013b. Between and betwixt soil fertility improvement and disease transmission : an assessment of the suitability of anaerobic digestion effluent for direct application as fertilizer. Nig. J. Technol. 32 (3), 492-497.

Alfa, I.M., Dahunsi, S.O., Iorhemen, O.T., Okafor, C.C., Ajayi, S.A., 2014a. Comparative evaluation of biogas production from poultry droppings, cow dung and lemon grass. Bioresour. Technol. 157, 270-277.

Alfa, M.I., Adie, D.B., Igboro, S.B., Oranusi, U.S., Dahunsi, S.O., Akali, D.M., 2014b. Assessment of biofertilizer quality and health implications of anaerobic digestion effluent of cow dung and chicken droppings. Renew. Energy 63, 681-686.

Alic, J.A., 2015. Biofuel battles: politics, policy, and the pentagon. Energy Res. Soc. Sci. 10, 10-18.

Aliyu, A.K., Modu, B., Tan, C.W., 2018. A review of renewable energy development in 
Africa: a focus in South Africa, Egypt and Nigeria. Renew. Sustain. Energy Rev. 8, 2502-2518.

Amigun, B., Sigamoney, R., von Blottnitz, H., 2008. Commercialisation of biofuel industry in Africa: a review. Renew. Sustain. Energy Rev. 12 (3), 690-711.

Amigun, B., Musango, J.K., Stafford, W., 2011. Biofuels and sustainability in Africa. Renew. Sustain. Energy Rev. 15 (2), 1360-1372.

Arndt, C., Benfica, R., Thurlow, J., 2011. Gender implications of biofuels expansion in Africa: the case of Mozambique. World Dev. 39 (9), 1649-1662.

Arthur, R., Baidoo, M.F., Antwi, E., 2011. Biogas as a potential renewable energy source: a Ghanaian case study. Renew. Energy 36 (5), 1510-1516.

Atabani, A.E., Silitonga, A.S., Badruddin, I.A., Mahlia, T.M.I., Masjuki, H.H., Mekhilef, S., 2012. A comprehensive review on biodiesel as an alternative energy resource and its characteristics. Renew. Sustain. Energy Rev. 16 (4), 2070-2093.

Austin, G., Morris, G., 2012. Biogas Production in Africa. . Dordrecht, The Netherlands.

Avery, L.M., Anchang, K.Y., Tumwesige, V., Strachan, N., Goude, P.J., 2014. Potential for Pathogen reduction in anaerobic digestion and biogas generation in SubSaharan Africa. Biomass Bioenergy 70, 112-124.

Avinash, A., Subramaniam, D., Murugesan, A., 2014. Bio-diesel-a global scenario. Renew. Sustain. Energy Rev. 29, 517-527.

Basha, S.A., Gopal, K.R., Jebaraj, S., 2009. A review on biodiesel production, combustion, emissions and performance. Renew. Sustain. Energy Rev. 13 (6-7), $1628-1634$.

Belward, A., Bisselink, B., Bódis, K., Brink, A., Dallemand, J.F., Roo, A.D., Huld, T., Kayitakire, F., Mayaux, P., Moner-Girona, M., Ossenbrink, H., Pinedo, I., Sint, H., Thielen, J., Szabó, S., Tromboni, U., Willemen, L., Monforti, F., Beward, A., 2012. Renewable Energies in Africa Institute for Environment and Sustainability.

Bensah, E.C., Antwi, E., Ahiekpor, J.C., 2010. Improving sanitation in Ghana-role of sanitary biogas plants. J. Eng. Appl. Sci. 5 (2), 125-133.

Betiku, E., Akintunde, A.M., Ojumu, T.V., 2016. Banana peels as a biobase catalyst for fatty acid methyl esters production using Napoleon's plume (Bauhinia monandra) seed oil: a process parameters optimization study. Energy 103, 797-806.

Blanchard, R., Richardson, D.M., O’Farrell, P.J., Von Maltitz, G.P., 2011. Biofuels and biodiversity in South Africa : review article. South Af. J. Sci. 107 (5 \& 6), 1-8.

Blanco, J., Michon, G., Carriere, S.M., 2017. Natural ecosystem mimicry in traditional dryland agroecosystems: insights from an empirical and holistic approach. J. Environ. Manag. 204 (Pt 1), 111-122.

Bracco, S., 2015. Effectiveness of EU biofuels sustainability criteria in the context of land acquisitions in Africa. Renew. Sustain. Energy Rev. 50, 130-143.

Bryant, S.T., Romijn, H.A., 2014. Not quite the end for Jatropha? Assessing the financial viability of biodiesel production from Jatropha in Tanzania. Energy Sustain. Dev. 23, 212-219.

Canabarro, N., Soares, J.F., Anchieta, C.G., Kelling, C.S., Mazutti, M.A., 2013. Thermochemical processes for biofuels production from biomass. Sustain. Chem. Proc. 1 (1).

Cheng, S., Li, Z., Mang, H.-P., Huba, E.-M., Gao, R., Wang, X., 2014. Development and application of prefabricated biogas digesters in developing countries. Renew. Sustain. Energy Rev. 34, 387-400.

Chirambo, D., 2016. Addressing the renewable energy financing gap in Africa to promote universal energy access: integrated renewable energy financing in Malawi. Renew. Sustain. Energy Rev. 62, 793-803.

Conigliani, C., Cuffaro, N., D’Agostino, G., 2018. Large-scale land investments and forests in Africa. Land Use Pol. 75, 651-660.

Dahunsi, S.O., 2019a. Liquefaction of pineapple peel: pretreatment and process optimization. Energy 185, 1017-1031.

Dahunsi, S.O., 2019b. Mechanical pretreatment of lignocelluloses for enhanced biogas production: methane yield prediction from biomass structural components. Bioresour. Technol. 280, 18-26.

Dahunsi, S., Oranusi, S.U., 2013. Co-digestion of food waste and human excreta for biogas production. Br. Biotechnol. J. 3 (4), 485-499.

Dahunsi, S.O., Oranusi, S., Owolabi, J.B., Efeovbokhan, V.E., 2016a. Comparative biogas generation from fruit peels of fluted pumpkin (Telfairia occidentalis) and its optimization. Bioresour. Technol. 221, 517-525.

Dahunsi, S.O., Oranusi, S., Owolabi, J.B., Efeovbokhan, V.E., 2016b. Mesophilic anaerobic co-digestion of poultry dropping and Carica papaya peels: modelling and process parameter optimization study. Bioresour. Technol. 216, 587-600.

Dahunsi, O.S., Oranusi, S., Efeovbokhan, E.V., 2017a. Anaerobic mono-digestion of Tithonia diversifolia (Wild Mexican sunflower). Energy Convers. Manag. 148, $128-145$.

Dahunsi, S.O., Oranusi, O., Efeovbokhan, V.E., 2017b. Pretreatment optimization, Process control, Mass and Energy balances and Economics of anaerobic codigestion of Arachis hypogaea (Peanut) hull and poultry manure. Bioresour. Technol. 241, 454-464.

Dahunsi, S.O., Oranusi, S., Efeovbokhan, V.E., 2017c. Cleaner energy for cleaner production: modeling and optimization of biogas generation from Carica papayas (Pawpaw) fruit peels. J. Clean. Prod. 156, 19-29.

Dahunsi, S.O., Oranusi, S., Efeovbokhan, V.E., 2017d. Optimization of pretreatment, process performance, mass and energy balance in the anaerobic digestion of Arachis hypogaea (Peanut) hull. Energy Convers. Manag. 139, 260-275.

Dahunsi, S.O., Oranusi, S., Owolabi, J.B., Efeovbokhan, V.E., 2017e. Synergy of Siam weed (Chromolaena odorata) and poultry manure for energy generation: effects of pretreatment methods, modeling and process optimization. Bioresour. Technol. 225, 409-417.
Dahunsi, S.O., Oranusi, S.U., Efeovbokhan, V.E., 2017f. Bioconversion of Tithonia diversifolia (Mexican sunflower) and poultry droppings for energy generation: optimization, mass and energy balances, and economic benefits. Energy Fuels 31 (5), 5145-5157.

Dahunsi, S.O., Olayanju, T.M.A., Adesulu-Dahunsi, A.T., 2019c. Data on optimization of bioconversion of fruit rind of Telfairia occidentalis (Fluted pumpkin) and poultry manure for biogas generation. Chemical Data Collections 20, 100-192.

Dahunsi, S.O., Olayanju, A., Izebere, J.O., Oluyori, A.P., 2018a. Data on energy and economic evaluation and microbial assessment of anaerobic co-digestion of fruit rind of Telfairia occidentalis (Fluted pumpkin) and poultry manure. Data Brief 21, 97-104.

Dahunsi, S.O., Oranusi, S., Efeovbokhan, V.E., Olayanju, A., Zahedi, S., Ojediran, J.O., Izebere, J.O., Aladegboye, O.J., 2018b. Anaerobic conversion of Chromolaena odorata (Siam weed) to biogas. Energy Rep. 4, 691-700.

Dahunsi, S.O., Oranusi, S., Efeovbokhan, V.E., Zahedi, S., Ojediran, J.O., Olayanju, A., Oluyori, A.P., Adekanye, T.A., Izebere, J.O., Enyinnaya, M., 2018c. Biochemical conversion of fruit rind of Telfairia occidentalis (fluted pumpkin) and poultry manure. Energy Sources, Part A: recov., Utiliz. Environ. Effects 40 (23), 2799-2811.

Dahunsi, S.O., Adesulu-Dahunsi, A.T., Izebere, J.O., 2019a. Cleaner energy through liquefaction of Cocoa (Theobroma cacao) pod husk: pretreatment and process optimization. J. Clean. Prod. 226, 578-588.

Dahunsi, S.O., Adesulu-Dahunsi, A.T., Osueke, C.O., Lawal, A.I., Olayanju, T.M.A., Ojediran, J.O., Izebere, J.O., 2019b. Biogas generation from Sorghum bicolor stalk: effect of pretreatment methods and economic feasibility. Energy Rep. 5, $584-593$.

Dahunsi, S.O., Osueke, C.O., Olayanju, T.M.A., Lawal, A.I., 2019d. Co-digestion of Theobroma cacao (Cocoa) pod husk and poultry manure for energy generation: effects of pretreatment methods. Bioresour. Technol. 283, 229-241.

Das, G.G., 2017. Food-feed-biofuel trilemma: biotechnological innovation policy for sustainable development. J. Pol. Model. 39 (3), 410-442.

Demirbas, A., 2005. Biodiesel production from vegetable oils via catalytic and noncatalytic supercritical methanol transesterification methods. Prog. Energy Combust. Sci. 31 (5-6), 466-487.

Efeovbokhan, V.E., Eboigbe, C., Oladimeji, T.E., Dahunsi, O.S., 2018. Deploying mathematical models for monitoring the quality of biodiesel products in biodiesel processing plants. Petrol. Coal 60, 6.

Estoppey, N., 2010. Evaluation of Small-Scale Biogas Systems for the Treatment of Faeces and Kitchen Waste: Case Study Kochi, South India. Swiss Federal Institute of Aquatic Science and Technology, Eawag (Dubendorf, Switzerland).

Ewing, M., Msangi, S., 2009. Biofuels production in developing countries: assessing tradeoffs in welfare and food security. Environ. Sci. Pol. 12 (4), 520-528.

Farooq, A., Amin, U.K., Abdullah, Y., 2016. Transesterification of oil extracted from different species of algae for biodiesel production. Afr. J. Environ. Sci. Technol. 7, $358-364$.

Gasparatos, A., von Maltitz, G.P., Johnson, F.X., Lee, L., Mathai, M., Puppim de Oliveira, J.A., Willis, K.J., 2015. Biofuels in sub-Sahara Africa: drivers, impacts and priority policy areas. Renew. Sustain. Energy Rev. 45, 879-901.

Giovannetti, G., Ticci, E., 2016. Determinants of biofuel-oriented land acquisitions in Sub-Saharan Africa. Renew. Sustain. Energy Rev. 54, 678-687.

Giwa, A., Alabi, A., Yusuf, A., Olukan, T., 2017. A comprehensive review on biomass and solar energy for sustainable energy generation in Nigeria. Renew. Sustain. Energy Rev. 69, 620-641.

Graef, F., Sieber, S., Mutabazi, K., Asch, F., Biesalski, H.K., Bitegeko, J., Bokelmann, W., Bruentrup, M., Dietrich, O., Elly, N., Fasse, A., Germer, J.U., Grote, U., Herrmann, L., Herrmann, R., Hoffmann, H., Kahimba, F.C., Kaufmann, B., Kersebaum, K.C., Kilembe, C., Kimaro, A., Kinabo, J., König, B., König, H., Lana, M., Levy, C., Lyimo-Macha, J., Makoko, B., Mazoko, G., Mbaga, S.H., Mbogoro, W., Milling, H., Mtambo, K., Mueller, J., Mueller, C., Mueller, K., Nkonja, E., Reif, C., Ringler, C., Ruvuga, S., Schaefer, M., Sikira, A., Silayo, V., Stahr, K., Swai, E., Tumbo, S., Uckert, G., 2014. Framework for participatory food security research in rural food value chains. Global Food Security 3 (1), 8-15.

Guo, M., Song, W., Buhain, J., 2015. Bioenergy and biofuels: history, status, and perspective. Renew. Sustain. Energy Rev. 42, 712-725.

Guzatto, R., de Martini, T.L., Samios, D., 2011. The use of a modified TDSP for biodiesel production from soybean, linseed and waste cooking oil. Fuel Process. Technol. 92 (10), 2083-2088.

Gwavuya, S.G., Abele, S., Barfuss, I., Zeller, M., Müller, J., 2012. Household energy economics in rural Ethiopia: a cost-benefit analysis of biogas energy. Renew. Energy 48, 202-209.

Hagos, K., Zong, J., Li, D., Liu, C., Lu, X., 2017. Anaerobic co-digestion process for biogas production: progress, challenges and perspectives. Renew. Sustain. Energy Rev. 76, 1485-1496.

Hanff, E., Dabat, M.-H., Blin, J., 2011. Are biofuels an efficient technology for generating sustainable development in oil-dependent African nations? A macroeconomic assessment of the opportunities and impacts in Burkina Faso. Renew. Sustain. Energy Rev. 15 (5), 2199-2209.

Harvey, L.D.D., 2014. Global climate-oriented building energy use scenarios. Energy Pol. 67, 473-487.

Herrmann, R., Jumbe, C., Bruentrup, M., Osabuohien, E., 2018. Competition between biofuel feedstock and food production: empirical evidence from sugarcane outgrower settings in Malawi. Biomass Bioenergy 114, 100-111.

Irena, 2013. Africa Renewable Energy Report the Path to Sustainable Growth. World Dev., pp. 84-98

Ishola, M.M., Brandberg, T., Sanni, S.A., Taherzadeh, M.J., 2013. Biofuels in Nigeria: a 
critical and strategic evaluation. Renew. Energy 55, 554-560.

Jagadevan, S., Banerjee, A., Banerjee, C., Guria, C., Tiwari, R., Baweja, M., Shukla, P., 2018. Recent developments in synthetic biology and metabolic engineering in microalgae towards biofuel production. Biotechnol. Biofuels 11 (1), 185.

Jain, S., Jain, P.K., 2017. The rise of Renewable Energy implementation in South Africa. Energy Proc 143, 721-726.

Janaun, J., Ellis, N., 2010. Perspectives on biodiesel as a sustainable fuel. Renew. Sustain. Energy Rev. 14 (4), 1312-1320.

Johnson, F.X., Matsika, E., 2006. Bio-energy trade and regional development: the case of bio-ethanol in southern Africa. Energy Sustain. Dev. 10 (1), 42-53.

Jumbe, C.B.L., Mkondiwa, M., 2013. Comparative analysis of biofuels policy development in Sub-Saharan Africa: the place of private and public sectors. Renew. Energy 50, 614-620.

Jumbe, C.B.L., Msiska, F.B.M., Madjera, M., 2009. Biofuels development in subsaharan Africa: are the policies conducive? Energy Pol. 37 (11), 4980-4986.

Kamp, L.M., Bermúdez Forn, E., 2016. Ethiopia's emerging domestic biogas sector: current status, bottlenecks and drivers. Renew. Sustain. Energy Rev. 60, 475-488.

Katuwal, H., Bohara, A.K., 2009. Biogas: a promising renewable technology and its impact on rural households in Nepal. Renew. Sustain. Energy Rev. 13 (9), $2668-2674$

Kgathi, D.L., Mmopelwa, G., Chanda, R., Kashe, K., Murray-Hudson, M., 2017. A review of the sustainability of Jatropha cultivation projects for biodiesel production in Southern Africa: implications for energy policy in Botswana. Agric. Ecosyst. Environ. 246, 314-324.

Landi, M., Sovacool, B.K., Eidsness, J., 2013. Cooking with gas: policy lessons from Rwanda's national domestic biogas program (NDBP). Energy Sustain. Dev. 17, $347-356$.

Liousse, C., Assamoi, E., Criqui, P., Granier, C., Rosset, R., 2014. Explosive growth in African combustion emissions from 2005 to 2030. Environ. Res. Lett. 9 (3).

Mahmudul, H.M., Hagos, F.Y., Mamat, R., Adam, A.A., Ishak, W.F.W., Alenezi, R., 2017. Production, characterization and performance of biodiesel as an alternative fuel in diesel engines - a review. Renew. Sustain. Energy Rev. 72, 497-509.

Mandelli, S., Barbieri, J., Mattarolo, L., Colombo, E., 2014. Sustainable energy in Africa: a comprehensive data and policies review. Renew. Sustain. Energy Rev. 37, 656-686.

Maqhuzu, A.B., Yoshikawa, K., Takahashi, F., 2017. Biofuels from agricultural biomass in Zimbabwe: feedstock availability and energy potential. Energy Proc 142, $111-116$.

Martin, I.I., William, J., Glass, R.I., Balbus, J.M., Collins, F.S., 2011. A major environmental cause of death. Sci 344, 180-181.

Mengistu, M.G., Simane, B., Eshete, G., Workneh, T.S., 2016. Factors affecting households' decisions in biogas technology adoption, the case of Ofla and Mecha Districts, northern Ethiopia. Renew. Energy 93, 215-227.

Mohammed, M., Egyir, I.S., Donkor, A.K., Amoah, P., Nyarko, S., Boateng, K.K., Ziwu, C., 2017. Feasibility study for biogas integration into waste treatment plants in Ghana. Egypt. J. Petrol. 26 (3), 695-703.

Muller, C., 2007. Anaerobic Digestion of Biodegradable Solid Waste in Low and Middle-Income Countries,. Swiss Federal Institute of Aquatic Science and Technology (Eawag). Department of Water and Sanitation in Developing Countries (Sandec, Switzerland.

Mulugetta, Y., 2009. Evaluating the economics of biodiesel in Africa. Renew. Sustain. Energy Rev. 13 (6-7), 1592-1598.

Mungwe, J.N., Colombo, E., Adani, F., Schievano, A., 2016. The fixed dome digester: an appropriate design for the context of Sub-Sahara Africa? Biomass Bioenergy 95, 35-44.

Murphy, J., Braun, R., Weiland, P., Wellinger, A., 2011. Biogas from crop digestion. IEA bioenergy 4-23.

Mwirigi, J., Balana, B.B., Mugisha, J., Walekhwa, P., Melamu, R., Nakami, S., Makenzi, P., 2014. Socio-economic hurdles to widespread adoption of smallscale biogas digesters in Sub-Saharan Africa: a review. Biomass Bioenergy 70, $17-25$.

Nigam, P.S., Singh, A., 2011. Production of liquid biofuels from renewable resources. Prog. Energy Combust. Sci. 37 (1), 52-68.

Nzila, C., Dewulf, J., Spanjers, H., Tuigong, D., Kiriamiti, H., van Langenhove, H., 2012 Multi criteria sustainability assessment of biogas production in Kenya. Appl. Energy 93, 496-506.

Ohimain, E.I., 2013. Can the Nigerian biofuel policy and incentives (2007) transform Nigeria into a biofuel economy? Energy Pol. 54, 352-359.

Ohimain, E.I., Izah, S.C., 2017. A review of biogas production from palm oil mill effluents using different configurations of bioreactors. Renew. Sustain. Energy Rev. 70, 242-253.

Okello, C., Pindozzi, S., Faugno, S., Boccia, L., 2013. Development of bioenergy technologies in Uganda: a review of progress. Renew. Sustain. Energy Rev. 18, 55-63.

Owamah, H.I., Alfa, M.I., Dahunsi, S.O., 2014a. Optimization of biogas from chicken droppings with Cymbopogon citratus. Renew. Energy 68, 366-371.

Owamah, H.I., Dahunsi, S.O., Oranusi, U.S., Alfa, M.I., 2014b. Fertilizer and sanitary quality of digestate biofertilizer from the co-digestion of food waste and human excreta. Waste Manag. 34 (4), 747-752.

Peterson, E.E., Cunningham, S.A., Thomas, M., Collings, S., Bonnett, G.D., Harch, B., 2017. An assessment framework for measuring agroecosystem health. Ecol.
Indicat. 79, 265-275.

Philbrook, A., Alissandratos, A., J, C., 2013. Biochemical processes for generating fuels and commodity chemicals from lignocellulosic biomass. Environ. Biotechnol. N. Approaches Prospect. Appl. https://doi.org/10.5772/55309.

Piker, A., Tabah, B., Perkas, N., Gedanken, A., Singh, S.P., Singh, D., 2017. Transesterification of soybean oil to biodiesel using $\mathrm{CaO}$ as a solid base catalyst. Fuel $87,1-9$.

Pradhan, A., Mbohwa, C., 2014. Development of bioenergy in South Africa: challenges and opportunities. Renew. Sustain. Energy Rev. 39, 1089-1100.

Qi, X., Zhang, S., Wang, Y., Wang, R., 2005. Advantages of the integrated pig-biogasvegetable greenhouse system in North China. Ecol. Eng. 24 (3), 175-183.

Rahman, M.A., Aziz, M.A., Ruhul, A.M., Rashid, M.M., 2017. Biodiesel production process optimization from Spirulina maxima microalgae and performance investigation in a diesel engine. J. Mech. Sci. Technol. 31 (6), 3025-3033.

Renzaho, A.M.N., Kamara, J.K., Toole, M., 2017. Biofuel production and its impact on food security in low and middle income countries: implications for the post2015 sustainable development goals. Renew. Sustain. Energy Rev. 78, 503-516.

Romeu-Dalmau, C., Gasparatos, A., von Maltitz, G., Graham, A., Almagro-Garcia, J. Wilebore, B., Willis, K.J., 2018. Impacts of land use change due to biofuel crops on climate regulation services: five case studies in Malawi, Mozambique and Swaziland. Biomass Bioenergy 114, 30-40.

Roopnarain, A., Adeleke, R., 2017. Current status, hurdles and future prospects of biogas digestion technology in Africa. Renew. Sustain. Energy Rev. 67, 1162-1179.

Rupf, G.V., Bahri, P.A., de Boer, K., McHenry, M.P., 2015. Barriers and opportunities of biogas dissemination in Sub-Saharan Africa and lessons learned from Rwanda, Tanzania, China, India, and Nepal. Renew. Sustain. Energy Rev. 52, 468-476.

Rupf, G.V., Bahri, P.A., De Boer, K., McHenry, M.P., 2016. Broadening the potential of biogas in Sub-Saharan Africa: an assessment of feasible technologies and feedstocks. Renew. Sustain. Energy Rev. 61, 556-571.

Russo, V., von Blottnitz, H., 2017. Potentialities of biogas installation in South African meat value chain for environmental impacts reduction. J. Clean. Prod. 153 465-473.

Saladini, F., Vuai, S.A. Langat, B.K. Gustavsson, M. Bayitse, R. Gidamis, A.B. Belmakki, M., Owis, A.S., Rashamuse, K., Sila, D.N., Bastianoni, S., 2016. Sustainability assessment of selected biowastes as feedstocks for biofuel and biomaterial production by emergy evaluation in five African countries. Biomass Bioenergy 85, 100-108.

Schouten, M.A.C., Mathenge, R.W., 2010. Communal sanitation alternatives for slums: a case study of Kibera, Kenya. Phys. Chem. Earth, Parts A/B/C 35 (13-14), $815-822$.

Scott, S.A., Davey, M.P., Dennis, J.S., Horst, I., Howe, C.J., Lea-Smith, D.J., Smith, A.G., 2010. Biodiesel from algae: challenges and prospects. Curr. Opin. Biotechnol. 21 (3), 277-286.

Semwal, S., Arora, A.K., Badoni, R.P., Tuli, D.K., 2011. Biodiesel production using heterogeneous catalysts. Bioresour. Technol. 102 (3), 2151-2161.

Shane, A., Gheewala, S.H., Kafwembe, Y., 2017. Urban commercial biogas power plant model for Zambian towns. Renew. Energy 103, 1-14.

Sikarwar, V.S., Zhao, M., Fennell, P.S., Shah, N., Anthony, E.J., 2017. Progress in biofue production from gasification. Prog. Energy Combust. Sci. 61, 189-248.

Simpson, T., 2009. Biofuels: the past, present, and a new vision for the future. BioSci 59 (11), 926-927.

Singh, M., 2006. Economics of biofuels for the transport sector in South Africa. Energy Sustain. Dev. 10 (2), 40-47.

Su, X., Xu, J., Liang, B., Duan, H., Hou, B., Huang, Y., 2016. Catalytic carbon dioxide hydrogenation to methane: a review of recent studies. J. Energy Chem. 25 (4), 553-565.

Surendra, K.C., Takara, D., Hashimoto, A.G., Khanal, S.K., 2014. Biogas as a sustainable energy source for developing countries: opportunities and challenges. Renew. Sustain. Energy Rev. 31, 846-859.

Tatsidjodoung, P., Dabat, M.-H., Blin, J., 2012. Insights into biofuel development in Burkina Faso: potential and strategies for sustainable energy policies. Renew. Sustain. Energy Rev. 16 (7), 5319-5330.

Session Thirteenth, Centre Vienna International, 2009. Round Table towards Sus tainable Biofuels Industries in Africa Briefing Note.

Torretta, V., Conti, F., Leonardi, M., Ruggieri, G., 2012. Energy recovery from sludge and sustainable development: a Tanzanian case study. Sustainability 4 2661-2672.

Weiland, P., 2006. State of the art of solid-state digestion-recent developments. In: Rohstoffe, F.N. (Ed.), Solid-State Digestion-State of the Art and Further R\&D Requirements. Gulzower Fachgesprä Che., pp. 22-38

World Health Organization, 2000. Addressing the Links between Indoor Air Pollution, Household Energy and Human Health: Based on the WHO-USAID Global Consultation on the Health Impact of Indoor Air Pollution and Household Energy in Developing Countries (Meeting Report).

Ye, W. Gao, Y., Ding , H., Liu, M., Liu, S., Han, X. 2016. Kinetics of transesterification of palm oil under conventional heating and microwave irradiation, using $\mathrm{CaO}$ as heterogeneous catalyst. Fuel 180, 574-579.

Zahedi, S., Dahunsi, S.O., Perez, M., Solera, R., 2018. Assessment of chemical inhibitor addition to improve the gas production from biowaste. Waste Biom Valor 10 (5), 1091-1099. 